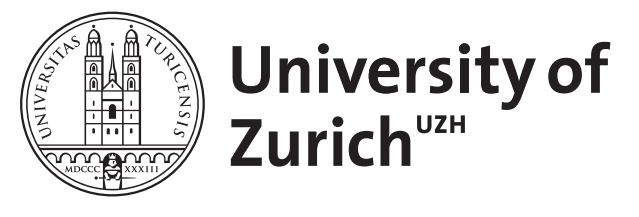

\title{
Credit Supply and Demand in Unconventional Times
}

\author{
Altavilla, Carlo ; Boucinha, Miguel ; Holton, Sarah ; Ongena, Steven
}

\begin{abstract}
Do borrowers demand less credit from banks with weak balance sheet positions? To answer this question we use novel bank-specific survey data matched with confidential balance sheet information on a large set of euro area banks. We find that, following a conventional monetary policy shock, bank balance sheet strength influences not only credit supply but also credit demand. The resilience of lenders plays an important role for firms when selecting whom to borrow from. We also assess the impact on credit origination of unconventional monetary policies using survey responses on the exposure of individual banks to quantitative easing and negative interest rate policies. We find that both policies do stimulate loan supply even after fully controlling for bank-specific demand, borrower quality, and balance sheet strength.
\end{abstract}

DOI: https://doi.org/10.1111/jmcb.12792

Posted at the Zurich Open Repository and Archive, University of Zurich ZORA URL: https://doi.org/10.5167/uzh-210389

Journal Article

Published Version

Originally published at:

Altavilla, Carlo; Boucinha, Miguel; Holton, Sarah; Ongena, Steven (2021). Credit Supply and Demand in Unconventional Times. Journal of Money, Credit and Banking, 53(8):2071-2098.

DOI: https://doi.org/10.1111/jmcb.12792 


\section{EUROPEAN CENTRAL BANK}

EUROSYSTEM

\section{Working Paper Series}

Carlo Altavilla, Miguel Boucinha, Sarah Holton, Steven Ongena
Credit supply and demand in unconventional times

\section{No 2202 / November 2018}

Disclaimer: This paper should not be reported as representing the views of the European Central Bank (ECB). The views expressed are those of the authors and do not necessarily reflect those of the ECB. 


\begin{abstract}
Do borrowers demand less credit from banks with weak balance sheet positions? To answer this question we use novel bank-specific survey data matched with confidential balance sheet information on a large set of euro area banks. We find that, following a conventional monetary policy shock, bank balance sheet strength influences not only credit supply but also credit demand. The resilience of lenders plays an important role for firms when selecting whom to borrow from. We also assess the impact on credit origination of unconventional monetary policies using survey responses on the exposure of individual banks to quantitative easing and negative interest rate policies. We find that both policies do stimulate loan supply even after fully controlling for bank-specific demand, borrower quality, and balance sheet strength.
\end{abstract}

JEL: E51, G21.

Keywords: credit demand and supply, bank lending survey, balance sheet strength, nonstandard monetary policy 


\section{Non-technical summary}

The conventional wisdom in banking literature is that balance sheet characteristics of financial intermediaries influence their ability to supply credit to households and firms. Weak banks tend to originate less credit. This paper studies whether weak banks also face less demand, owing to borrowers diverting their demand for credit towards banks with more solid balance sheets. We address this thus far neglected question using a novel dataset of individual banks' responses on their credit supply and demand conditions linked to their balance sheets. Understanding the transmission of shocks to the real economy via banks and accounting for credit demand is vital when accurately assessing the impact of monetary policies. With this in mind, we additionally analyse how the strength of this "demand channel" interacts with conventional and unconventional monetary policy measures.

We contribute to the literature in a number of ways. The so-called "bank lending channel" literature is devoted to identifying the effects of credit supply shocks, controlling for possible changes in demand, using assumptions of varying strength. We assess the validity of some of these assumptions using demand directly reported by individual banks. There are papers suggesting that firms' credit demand may not be homogenous across banks owing to bank specialisation, location or even quality. We extend on this literature by examining whether changes in monetary policy have a differential effect on demand owing to banks' resilience. In addition, we contribute to the literature concerned with assessing the effects of unconventional monetary policies on lending by exploring survey responses on the exposure of individual banks to quantitative easing and negative interest rate policies and controlling for the demand they face.

We find that, following a conventional monetary policy shock, bank balance sheet strength influences not only credit supply but also credit demand. The resilience of lenders plays an important role for firms when selecting whom to borrow from. With respect to the effect of unconventional monetary policies on lending, we find that both quantitative easing and the negative interest rate policy stimulated loan supply, even when taking into account bank-specific demand, the quality of the borrower pool, and balance sheet strength. We provide confirmation of the hypothesised channels of each policy by showing that banks with higher sovereign bond holdings extended more credit following the announcement of the quantitative easing programme and that banks with higher excess liquidity holdings had stronger credit flows after the introduction of negative deposit facility rates. 


\section{Introduction}

The conventional wisdom in the banking literature is that balance sheet characteristics of financial intermediaries influence their ability to supply credit to households and firms (e.g., Kashyap and Stein (2000)). In a time of monetary contraction, for example, weak banks will tend to grant less credit. In this paper we study whether weak banks may also face less demand, as borrowers might concurrently divert their demand for credit towards banks with more solid balance sheet positions in order to avoid having to deal with a constrained bank or even - in bankruptcy with a bank receiver. We show that the impact of a standard monetary policy shock on credit demand varies across banks depending on their resilience, and using this measure of bank specific demand, we estimate the impact of non-standard monetary policy measures specifically on bank credit supply.

Understanding the transmission of shocks to the real economy via banks is of utmost importance as optimal policy responses depend on whether credit developments are driven by changes in banks' willingness to lend or in borrowers' propensity to invest or consume. There is a large literature, known as the "bank lending channel", ${ }^{1}$ concerned with identifying how credit supply shocks can vary across different types of banks by controlling for possible changes in demand using assumptions of varying strength. A topic that has received much less attention is whether credit demand can also vary across banks depending on their characteristics. We disentangle the role of supply and demand in determining credit dynamics using two main ingredients: a proxy for monetary policy shocks and an indicator of bank-specific credit demand conditions. For both we rely heavily on a novel dataset of individual euro area credit institutions Bank Lending Survey (iBLS) responses, which provides bank specific information on credit supply, demand and the impact of monetary policy. By linking individual banks' responses on how they are affected by the negative deposit facility rate and the quantitative easing programme to hard data on their loans and other key balance sheet variables, and effectively controlling for credit demand they face, we can quantify the effects of these policy measures on credit provision during these recent unconventional years.

The Bank Lending Survey (BLS) was established to complement hard data on lending flows with information on supply and demand conditions and there is a large literature using this survey to analyse the determinants of credit growth. As banks report specifically on how, and why, loan supply and demand pressures are changing, survey data can provide a cleaner identifi-

\footnotetext{
${ }^{1}$ See for instance, Bernanke and Blinder (1992), Kashyap and Stein (2000), Jiménez, Ongena, Peydró and Saurina (2012).
} 
cation of the drivers of credit developments, without the need for assumptions on demand. Past literature shows that survey measures of credit supply and demand have significant explanatory power for aggregate credit and economic developments in the US (Lown and Morgan (2006)), the euro area (de Bondt, Maddaloni, Peydró and Scopel (2010)) and for individual countries (see for instance, Blaes (2011) for Germany and Del Giovane, Eramo and Nobili (2011) for Italy). Moreover, survey evidence shows that the transmission of monetary policy can change, in particular during periods of stress (Ciccarelli, Maddaloni and Peydró (2013); Altavilla, Darracq Pariès and Nicoletti (2015)), and that monetary policy shocks can be amplified through the bank lending channel (Ciccarelli, Maddaloni and Peydró (2015)).

This paper adds to the broader bank lending channel literature concerned with identifying the effects of credit supply shocks, by controlling for possible changes in demand. This literature employs a wide range of methodologies based on different assumptions regarding demand. Kashyap and Stein (2000) show that lending activity responds differently to a monetary policy shock depending on banks' liquidity; by assuming that demand is not systematically different across banks according to their liquidity position, they attribute this variation to supply. However, the possibility that firms that are more affected by certain shocks also tend to be customers of the more affected banks (i.e., they are not randomly sorted across banks), may cast doubt on the validity of this assumption and has led to the use of more granular data. For instance, by using firm "clusters", across characteristics such as industry, location, size and/or risk, and by assuming that credit demand is generally homogenous within these clusters, variation in lending across different types of banks can then be attributed to supply (Popov and Van Horen (2015); Acharya, Eisert, Eufinger and Hirsch (2017); Degryse, De Jonghe, Jakovljevic, Mulier and Schepens (2018)). The most rigorous identification strategy uses credit exposure data at the bank-firm level and controls for changes in demand at the individual borrower level by using firm-time fixed effects, which in the literature is by now widely known as using a Khwaja and Mian (2008) type estimation strategy. The implementation of this strategy is based on firms that have multiple bank relationships, under the assumption that any change in lending to the same firm by different banks is driven by changes in credit supply.

There are two possible caveats even with these rich granular data methods to identify supply. As shown in Degryse, De Jonghe, Jakovljevic, Mulier and Schepens (2018), ${ }^{2}$ the characteristics of firms with multiple lending relationships tend to differ from those with single relationships

\footnotetext{
${ }^{2}$ For a data set of recent Belgian bank-firm exposures, they compare estimates of bank supply shocks derived using firm cluster (industry-location-size) - time fixed effects and those using firm-time fixed effects and find that despite these differences the estimates obtained under each method are similar.
} 
(the former tend to be older and bigger) and the credit supply measure derived using only the sample of multiple-bank firms is substantially different from the one derived using also singlebank firms. Secondly, it is possible that demand can vary, not just at the firm level, but also at the bank-firm level, which can complicate the identification of supply shocks using firm time fixed effects. Past literature has highlighted a number of factors that might influence a firm's choice of bank, such as bank proximity (Degryse and Ongena (2005)), size (Berger and Udell (2002), Berger et al. (2005)), specialisation (Paravisini, Rappoport and Schnabl (2014), Paravisini, Rappoport, Schnabl and Wolfenzon (2015)) and capital position (Holmstrom and Tirole (1997), Schwert (2018)). In line with the latter literature, Khwaja and Mian (2008) acknowledged that a potential problem with their approach is that it fails to capture "strategic withdrawal" by firms from banks with balance sheet problems for fear that the bank will become insolvent. There is even evidence that borrowers may be willing to pay for bank capital strength (Kim, Kristiansen, Vale, 2005). Anticipating the possibility of bank insolvency, bank-dependent firms may match with well capitalized banks, while firms with access to the bond market might borrow from

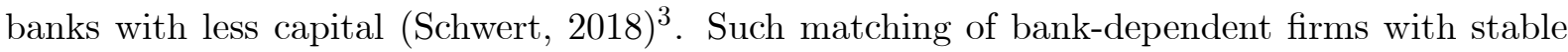
banks smooths cyclicality in aggregate credit provision and mitigates the effects of bank shocks on the real economy. In order to shed light on the relevance of these concerns and account for firm - bank matching outcomes, we use banks' own reported credit demand from the BLS.

A number of existing theories imply that credit demand should be higher for more resilient banks. First, firms may want to align themselves with stronger banks in order to signal their quality. Billett, Flannery and Garfinkel (1995) find strong evidence that loan announcements with higher quality lenders are associated with significantly higher abnormal returns to the firm's stock price, implying that a loan from a strong bank conveys more positive information about the borrower's prospects. Second, as already mentioned, banks with stronger balance sheets are capable of maintaining loan growth when faced with a shock, such as a contraction in monetary policy (Kishan and Opiela, 2000; Kashyap and Stein, 2000; Gambacorta and Mistrulli, 2004). Third, models of relationship lending show that firms cannot seamlessly communicate information that banks obtain about them over the course of a relationship to other outside banks. Therefore, firms that need to switch banks (either owing to bank credit constraints or collapse) could pay a higher interest rate (Sharpe (1990) and Rajan (1992)). In order to avoid such a fate, we posit that demand at more sound banks will in general be higher, as firms try

\footnotetext{
${ }^{3}$ Another well-documented matching is that large and physically remote firms may borrow from centralized "large" banks that rely on hard information (Stein (2002); Petersen and Rajan (2002); Cole, Goldberg and White (2004); Berger, Miller, Petersen, Rajan and Stein (2005)).
} 
to establish and maintain relationships with more resilient institutions.

We also contribute to the literature on the effects of non-standard monetary policy on credit. Previous results on the link between large scale asset purchase programmes and bank lending include, among others, Bowman, Cai, Davies and Kamin (2015) for Japan, Rodnyansky and Darmouni (2017) for the US and Joyce and Spaltro (2014) for the UK. In general these studies provide evidence of a significant impact of Quantitative Easing (QE) on bank lending. In the same vein, evidence for the euro area suggests that the ECB's asset purchase programme (henceforth, APP) led to a significant decline in lending rates and to an increase in credit to the private sector (Altavilla, Giannone and Lenza (2016); Albertazzi, Becker and Boucinha (2018)). Existing evidence on the effect of the introduction of negative interest rates is less clear. Demiralp, Eisenschmidt and Vlassopoulos (2017) and Bottero et al. (2018) for example find a positive effect on the supply of loans, by comparing banks with different levels of excess liquidity holdings and different amounts of interbank loans respectively. At the same time, recent studies document a possible impact of the negative deposit facility rate (henceforth DFR) on banks' risk taking. Nucera, Lucas, Schaumburg and Schwaab (2017) find that the impact of the introduction of negative interest rates on bank risk is moderate, despite some heterogeneity across business models, with banks relying more on deposit funding being perceived by the market as more risky. Based on data for syndicated loans, Heider, Saidi and Schepens (2017) find that banks with higher deposit ratios increase risk-taking by relatively more following the introduction of the negative DFR, suggesting that banks whose margin is more negatively affected by the policy can try to recoup profitability by increasing risk-taking. In parallel, Arce, García-Posada, Mayordomo and Ongena (2018) find that banks whose net interest income is negatively affected by the introduction of the negative DFR, and who are more capital constrained, react by applying relatively stricter terms and conditions for the approval of loans, which is consistent with an attempt to increase the regulatory capital ratio by decreasing risk weights.

Our findings provide important contributions to all these branches of the literature. Firstly, we show that both credit supply and demand are important determinants of credit volume and that, in line with previous studies, supply is more relevant during crisis periods. Secondly, we show evidence that not only loan supply, but also demand can vary across banks depending on their strength. Finally, using the measure of demand as reported by banks for identification, we show that quantitative easing and the negative deposit facility supported loan supply.

The paper proceeds as follows. Section 2 provides an overview of the dataset and some stylised facts. Section 3 outlines the main empirical findings on how credit growth is influenced by demand and supply and on the impact of unconventional monetary policies on banks' lending 
behaviour. Section 4 concludes.

\section{Data and Stylised Facts}

This section summarises the data used in the empirical analysis and provides an overview of developments in bank lending, credit supply, credit demand, and the possible impact of unconventional monetary policies. Individual banks' BLS responses on the unconventional measures are particularly useful as they provide a direct measure of exposure to the specific policy shocks and therefore should not in principle be confounded by any other concurrent event.

\subsection{Lending activity, credit supply and demand}

Our main source of data is a novel confidential data set on iBLS - a survey containing selfreported information on banks' credit supply and demand developments. Our dataset contains quarterly information from 2002Q4 to 2017Q4 on supply and demand conditions in credit markets for an unbalanced panel of 116 banks across 13 countries in the euro area. ${ }^{4}$ We match this dataset with individual banks' lending data and other balance sheet characteristics from the individual balance sheet information (iBSI) dataset which starts in mid-2007. As there are sometimes multiple monetary financial institutions (MFIs) linked to one BLS bank (for instance in the case there are separate mortgage and corporate MFIs that report as one BLS bank), we have 134 MFIs with balance sheet information. Nevertheless we will henceforth refer to MFIs as "banks". We also use some market sources of information, such as bank CDS spreads from ICE CMA. ${ }^{5}$

Developments in loan supply and demand, two of the most important variables we use from the BLS, are displayed in Figure 1 for our sample of banks. It shows the easing of standards and the increase in credit demand in the run up to the crisis and the tightening of credit standards and fall in demand at the onset of the crisis. While both supply and demand conditions eased somewhat during 2009, they deteriorated again as the sovereign debt crisis took hold. In the most recent years (in particular since the inception of the credit and quantitative easing packages) credit supply has been easing and demand has been increasing. Notable from the chart, is the significant correlation between measures of credit supply and demand, which both tend to follow the economic cycle. The correlation between supply and demand is not something that

\footnotetext{
${ }^{4}$ The countries included are: Austria, Belgium, Germany, Estonia, Spain, France, Ireland, Italy, Lithuania, Luxembourg, Netherlands, Portugal and Slovakia.

${ }^{5}$ For more details on data definitions and sources, please see Table 1.
} 
is relevant only in the euro area; data for the US and UK also show that measures of supply and demand tend to move together (Figure 2). This co-movement highlights the difficulty in disentangling supply from demand, though it is crucial for any analysis of credit developments. The correlation between credit supply and demand is obviously in part driven by developments in the macro-economy. However, the granular data we have access to allows us to fully control for the macro developments that drive part of this co-movement, and to uniquely examine whether individual bank characteristics influence individual bank demand.

Also noteworthy, is the preponderance of banks reporting "no impact" in particular for credit standards and the dearth of easing episodes reported by banks. Owens and Schreft (1995) document a similar lack of loosening credit standards and a high reported tendency of unchanged responses for the US. However, notwithstanding the high incidence of unchanged responses, the net responses of banks in each round provide substantial information on changing conditions and developments in credit, as shown by the high correlation between credit growth and supply and demand in Figure 3. Overall, while the sample is only a subset of the euro area survey, it covers around $80 \%$ of the total BLS sample in terms of the total volume of credit and a consistency analysis shows very strong correlations between the aggregated results for the subsample and the total sample. Moreover, as the sample of banks included in the iBLS includes the most important banks for a wide range of euro area countries (including the 5 largest), credit developments in our sample of banks closely track the euro area aggregate developments, as shown in Figure 4, indicating the relevance of our findings for the euro area as a whole.

\subsection{Negative interest rate policy in the euro area}

Since the onset of the financial crisis, the ECB and all other major central banks reacted by providing significant monetary policy accommodation. In particular, the ECB introduced a package of credit easing measures in June 2014, following a sustained period of disinflation and the emergence of concerns about the potential for outright deflation. These measures included the introduction of a negative interest rate on the deposit facility (on reserves in excess of the minimum reserve requirements). There are two main channels through which this policy is expected to impact bank lending supply. On the one hand, cutting interest rates (below zero) reduces banks' funding costs. On the other hand, negative rates on the deposit facility increase the opportunity cost of holding excess reserves with the central bank. By charging banks for excess liquidity, the policy aims to provide further stimulus by prompting balance sheet adjustments by banks who are trying to minimise the cost incurred by the policy. One such 
way that banks can reduce their cash holdings, and consequently the charge on this liquidity, is by extending loans to the real economy (e.g., Demiralp, Eisenschmidt and Vlassopoulos (2017)). Under this rationale, one would expect any stimulatory effects on lending to be strongest for those banks with higher excess liquidity holdings, as their income is most explicitly impacted by the charge.

Figure 5 shows that the deposit facility rate descended increasingly into negative territory from the first cut of 10 basis points below zero in June 2014 to minus 40 basis points in March 2016, at which point it stabilised. The figure also shows that levels of excess liquidity were low at the introduction of negative rates and began to increase with the introduction of the expanded asset purchase programme in the first quarter of 2015, illustrating the important interaction between these two policies. In the BLS, banks report directly on the effects of the negative interest rate policy on their income, so that we can assess whether there is in fact evidence that the lending flows at banks more exposed to the policy did in fact exhibit more positive developments in supply.

\subsection{Quantitative easing in the euro area}

In January 2015, with the inflation outlook further deteriorated and with little scope for further declines in interest rates, the ECB announced a quantitative easing policy - the expanded APP - in order to provide further monetary policy accommodation. Since its introduction, there have been a number of recalibrations in this programme, as shown in Figure 6. The monthly pace of the purchases was originally set at $€ 60 \mathrm{bn}$ starting in March 2015, increased to $€ 80 \mathrm{bn}$ in March 2016 and decreased to $€ 60 \mathrm{bn}$ in April 2017. Following the recalibration of the programme in October 2017 the pace of monthly purchases was set to $€ 30 \mathrm{bn}$ a month from January 2018 until at least September 2018. Finally, in June 2018, the Governing Council announced a further reduction in the net asset purchases to $€ 15$ billion until the end of December 2018, at which point purchases are expected to end. Quantitative easing can support bank credit supply through a number of channels. Asset purchases increase bank liquidity directly through the sales of bonds by banks and indirectly through an increase in deposits owing to their costumers' bond sales. As central banks purchase sovereign assets, the prices of these assets increase and their yields decrease. Banks who sell these assets will consequently have capital gains which can ease leverage constraints and enhance credit supply. Therefore, we would expect that banks that had higher holdings of sovereign bonds at the start of the programme would have been more prone to positive impulses on lending. Moreover, depressing the yields on safe assets should make 
alternatives investments, such as lending to the real economy, more attractive.

Figure 7 illustrates the negative correlation between sovereign bond holdings and lending to the non-financial private sector that is suggested in the literature on the effects of quantitative easing. We can use the BLS information that individual banks report on the impact of the asset purchases on their liquidity to assess whether these banks indeed saw a more positive effect on their lending.

In the next section we formally assess the relationship between loan growth and credit supply and demand measures (Section 3.1). Moreover, we use a financial market measure of balance sheet constraints to assess whether, as documented for credit supply (Kashyap and Stein (2000)), the response of demand to monetary policy shocks also differs according to bank strength (Section 3.2). Finally, using the measure of demand as reported by banks for identification, we assess the impact of recent unconventional monetary policy measures on loan supply (Section 3.3).

\section{$3 \quad$ Empirical Evidence}

This section provides empirical evidence on: i) the dependence of credit growth on demand and supply; ii) the impact of an exogenous shock on credit demand and supply and its interaction with bank balance sheet strength; and, iii) the impact of ECB unconventional measures on lending growth.

\subsection{Actual credit developments, and BLS supply and demand}

Before proceeding with our analysis of credit supply and demand, it is necessary to ascertain how informative these measures are for actual lending developments. To do so we estimate the following equation:

$$
\begin{aligned}
\Delta \text { Loans }_{b, c, t}= & \alpha_{b}+\delta_{c, t}+\sum_{n=1}^{4} \beta_{n} \Delta \text { Loans }_{b, c, t-n} \\
& +\gamma_{1} \Delta \text { Credit Supply } \text { S }_{b, c, t}+\gamma_{2} \Delta \text { Credit Demand } \\
b, c, t & +\epsilon_{b, c, t}
\end{aligned}
$$

where $\Delta$ Loans $_{b, c, t}$ is the quarter-on-quarter growth rate of the total loan volume to nonfinancial corporations (NFC) by bank $b$ in country $c$ in quarter $t . \alpha_{b}$ are bank fixed effects. $\delta_{c, t}$ are country-time (in this case quarter) fixed effects. ${ }^{6}$

\footnotetext{
${ }^{6}$ Definitions and descriptive statistics of all variables used are presented in Table 1.
} 
$\Delta$ Credit Supplyb,c,t is defined using the following question from the BLS: "Over the past three months, how have your bank's credit standards as applied to the approval of loans or credit lines to enterprises changed?" The responses take a five-point scale: 1 "Tightened considerably", 2 "Tightened somewhat", 3 "Remained unchanged", 4 "Eased somewhat" and 5 "Eased considerably."

$\Delta$ Credit Demand ${ }_{b, c, t}$ is obtained using the following question from the BLS: "Over the past three months, how has the demand for loans or credit lines to enterprises changed at your bank, apart from normal seasonal fluctuations?" And again the responses take a five-point scale: 1 "Decreased considerably", 2 "Decreased somewhat", 3 "Remained unchanged", 4 "Increased somewhat" and 5 "Increased considerably".

Results in Table 2 show that credit developments are jointly affected by supply and demand pressures, not only in a statistically, but also in an economically relevant manner. The first column in the table shows results from a panel estimation with random effects; the second column shows the results including bank fixed effects and finally column 3 shows the results including both bank and country-time fixed effects. Comparing the coefficients across the columns, we can see that the inclusion of bank fixed effects diminishes the coefficient on supply substantially, which likely indicates the importance of fixed characteristics, such as a bank's business model, in determining their lending strategies. On the other hand the inclusion of bank fixed effects barely alters the coefficient on credit demand. When we saturate our model with country-time dummies, which completely control for any variation that may be coming from macroeconomic developments (at a country level in any time period), the coefficient on demand decreases, as one would expect considering the importance of these factors for credit demand. However, importantly, both supply and demand remain significant determinants of loan growth, with similar effects over the whole period.

The coefficient of $0.350^{* *}$ on credit supply indicates that an easing by one unit on the fivepoint scale corresponds to an increase at the individual bank level of credit growth by 35 basis points, while the coefficient of $0.366^{* *}$ on credit demand indicates that an increase by one unit on the five-point scale corresponds to an increase at the individual bank level of credit growth by 37 basis points. ${ }^{7}$ Trivially put, we need to account for both supply and demand when assessing credit growth. $^{8}$ This confirms the importance of the survey and its information content for loan

\footnotetext{
${ }^{7}$ As in the Tables, we indicate statistical significance as follows: *** Significant at $1 \%,{ }^{* *}$ significant at $5 \%, *$ significant at $10 \%$.

${ }^{8}$ We experimented with different lag structures and found that contemporaneous credit supply and demand have the highest explanatory power for quarter-on-quarter loan growth, which is in line with how the survey question is phrased (i.e., it refers to changes in the most recent period).
} 
developments.

Next, we estimate Equation (1) as a recursive regression starting with a five year window and collate the estimates of the coefficients of bank level supply and demand in Figure 8. The results show that the estimated coefficients on credit supply vary between 0.5 at the beginning of the sample, which largely reflects the crisis period, and around 0.35 in the later sample period, which includes the post-crisis period. The estimated coefficients are always statistically significant. The coefficients on credit demand hover between 0.25 and 0.35 throughout the sample period. These estimates suggest that actual bank credit growth and the survey measure of the bank credit supply strongly correspond, especially during the crisis period, while with the measure of credit demand in general there is a somewhat weaker correspondence.

\subsection{Balance sheet strength, credit demand and supply}

Next we estimate the impact of a monetary policy shock on credit supply and demand individually:

$$
\begin{aligned}
\Delta \text { Credit Supply } y_{b, c, t}= & \alpha_{b}+\delta_{c, t}+\sum_{n=1}^{4} \mu_{n} \Delta \text { Credit Supplyb,c,t-n}+\varpi \text { Shock }_{t-1} \\
& +\Gamma X_{b, c, t-1}+\Theta\left(\text { Shock }_{t-1} \times X_{b, c, t-1}\right)+\psi \text { Borrower risk } \epsilon_{b, c, t}+\epsilon_{b, c, t}
\end{aligned}
$$

$$
\begin{aligned}
\Delta{\text { Credit } \text { Demand }_{b, c, t}=} & \alpha_{b}+\delta_{c, t}+\sum_{n=1}^{4} \varphi_{n} \text { ACredit Demand } \\
& +\Lambda X_{b, c, c, t-1}+\Phi\left(\text { Shock }_{t-1} \times X_{b, c, t-1}\right)+\kappa \text { Borrower } \text { risk }_{b, c, t}+\epsilon_{b, c, t}
\end{aligned}
$$

Again $\alpha_{b}$ are bank fixed effects; $\delta_{c, t}$ are country-time dummies and $S h o c k_{t-1}$ is the change in the 3 month Euribor. This is similar to the monetary policy shock used in Bernanke and Blinder (1992) and Kashyap and Stein (2000). $X_{b, c, t-1}$ represent bank balance sheet constraints and are the changes in individual banks' CDS. We also include a measure of borrower risk from the BLS, as banks are asked with regard to their borrowers how the industry or firm-specific situation and outlook/borrower's creditworthiness has changed.

The results in Table 3 show that banks that had increases in their CDS spread, indeed had lower credit supply and demand, even when controlling for country time dummies. Moreover, the interaction term in the table in columns (1) and (3), respectively, shows that a contraction 
in monetary policy (increase in Euribor) will decrease both credit supply and demand more at banks with higher CDS spreads. This indicates that in the presence of a shock, weak balance sheets may not only alter banks' willingness or ability to supply credit, but it may also mean borrowers are more selective regarding their banks. This relationship also holds when controlling in columns (2) and (4), respectively, for changes in the risk profile of the firms that borrow from each bank. For consistency with results shown in other sub-sections, Table 3 is estimated from mid-2007, the period for which we have both lending and survey data. Nonetheless, when estimating equations 2 and 3 for the longer period, results are unchanged (not shown). Moreover, Table 4 shows that the result can be replicated by interacting the monetary policy indicator with other bank characteristics such as NPL, capital ratio and exposure to domestic sovereign bonds.

Overall these estimates on the interactive terms, especially for demand, are our key finding and cast doubt on identification strategies that solely rely on firm(-time) fixed effects, combined with bank characteristics, to isolate credit supply within-firm. If credit demand is also bankspecific, which is what the estimates in Tables 3 and 4 suggest, such a strategy cannot successfully disentangle supply from demand. Therefore, in the next section we fully account for bank-specific credit demand when assessing the impact on lending of the ECB's non-standard measures.

\subsection{Impact of non-standard monetary policy}

In this section we assess the impact on lending of the ECB's non-standard measures, focusing on the introduction of negative interest rates (DFR) and of the euro area's quantitative easing program, the so-called expanded Asset Purchase Programme (APP). We thereby effectively account for bank-specific demand for credit.

The analysis is based on the estimation for both policy measures of a difference-in-difference model as shown in equation (4) below. The dependent variable is the quarterly growth rate of loans to NFC for bank $b$ in country $c$ in quarter $t$. The model includes 4 lags of the dependent variable. Treated $d_{b, c}$ is a dummy variable equal to one for banks more impacted by the policy. For the negative DFR, treated banks are defined as those who on average reported that the impact of the negative interest rate policy on their net interest income was stronger. ${ }^{9}$ For the APP, treated banks are those who on average reported that the APP impact on their liquidity

\footnotetext{
${ }^{9}$ Banks' possible responses range from 1-5, where 3 corresponds to no impact and a lower (higher) number indicates a stronger (weaker) impact. Since the question has been asked regularly since the introduction of the programme, each bank's response is averaged through time. As the median of each bank's average response to this question is 2, using this value as a threshold would misclassify many banks who always reported an impact from the DFR as untreated. Therefore the threshold is set at the 75 th percentile (2.5) which is closer to the threshold of no impact (3) but still allows for an adequate control group.
} 
position was more positive. ${ }^{10}$ Post $_{t}$ is a dummy variable equal to one since the implementation of each policy. For the negative DFR, introduced on 11 June 2014, the post period starts in 2014 Q3. For the APP, which was announced in 22 January 2015, we define the implementation period since 2015 Q1.

Loan supply is identified by controlling for changes in demand reported by each bank in each quarter $\left(\Delta\right.$ Credit Demand $\left.d_{b, c, t}\right)$ and for fixed effects capturing all observable and unobservable bank characteristics which are time invariant $\left(\alpha_{b}\right)$ as well as for all factors which are countryspecific and time-variant, i.e. for the macroeconomic environment $\left(\delta_{c, t}\right)$. The model also controls for borrower credit risk as reported by each bank in the survey (Borrower risk $_{b, c, t}$ ) and for bank balance sheet characteristics $\left(X_{b, c, t-1}\right)$, a vector including leverage, size, amount borrowed in the targeted long term refinancing operations (TLTROs) and liquidity). $\beta_{1}$ is the main coefficient of interest, showing how the behaviour of treated banks changed after the implementation of the policy compared to untreated banks.

$$
\begin{aligned}
\Delta \text { Loans }_{b, c, t}= & \alpha_{b}+\delta_{c, t}+\sum_{n=1}^{4} \gamma_{n} \Delta \text { Loans }_{b, c, t-n}+\beta_{1}\left(\text { Treated }_{b, c} \times \text { Post }_{t}\right) \\
& +\beta_{3} \text { Treated }_{b, c}+\beta_{2} \text { Post }_{t}+\beta_{4} \Delta \text { Credit Demand } \text { Dem,c,t }_{b, t} \\
& +\beta_{5} \text { Bor row er risk } \text { rec, }_{b, t}+\Upsilon X_{b, c, t-1}+\epsilon_{b, c, t}
\end{aligned}
$$

BLS banks that reported a larger impact from the negative DFR and APP tended to show higher loan growth following the implementation of these policies (Figure 9). The figure displays the cumulated differences in quarterly growth rates between banks in the treatment and control groups for the negative DFR (in the left panel) and for the APP (in the right panel). As shown in Figure 9, no systematic difference is observable in loan growth across the groups of banks before the implementation of the measures. However, following the implementation of the measures, banks that reported being more affected clearly increased their lending growth by more than other banks. As already discussed, there are important interactions between the policies, as quantitative easing injects liquidity on which the negative rates apply. Therefore, we also analyse the consequences of being affected by both policies (relative to being affected by neither).

\footnotetext{
${ }^{10}$ Banks' possible responses range from $1-5$, where 3 corresponds to no impact and a higher (lower) number indicates a more positive (negative) impact. Since the question has been asked regularly since the introduction of the programme, each bank's response is averaged through time. The threshold is then set at 3.17 which corresponds to the median of the distribution of each bank's average response.
} 
Table 5 shows results for the estimation of equation 4 for the negative deposit facility rate, for quantitative easing and for the two measures combined; the three columns for each show the results with random effects, bank fixed effects and bank and country time fixed effects respectively. Results show that both the negative DFR and the APP led to an increase in the supply of bank loans and in particular supply increased for banks affected by both (relative to those affected by neither), which confirms that the policies reinforce each other. The coefficient on the interaction term is positive and statistically significant regardless of whether the model is estimated using pooled OLS models (columns 1, 4 and 7), including bank fixed-effects (columns 2, 5 and 8) and considering also country-time fixed effects (columns 3, 6 and 9). Therefore, banks more affected by each policy and in particular both policies, showed higher loan growth after its implementation, even after controlling for all macroeconomic effects, loan demand, borrower risk, bank characteristics and all other observable and unobservable differences across banks that are time invariant. As expected, increased loan demand is associated with higher loan growth in all specifications. The fact that the coefficient on demand remains significant even when country-time fixed effects are included indicates that loan demand differs across banks even within each country and time-period, confirming earlier findings and the need to include this variable in the specifications.

The robustness of these results is confirmed by the estimation of alternative specifications (Table 6). For these exercises, the level of excess liquidity and the sovereign bond holdings are used to proxy for the exposure of the individual banks to the negative DFR and APP, respectively. As mentioned in sections 2.2 and 2.3, these characteristics identify banks that should be most exposed to each of the policies and therefore are a means of illustration the transmission channels of the findings in Table 5. In the first and third columns, the balance sheet measure is lagged one quarter and varies not only across banks, but also within banks over time. In the second and fourth columns, the balance sheet measure is fixed at the level observed at the inception of each policy, i.e., June 2014 for the DFR and December 2014 for sovereign bond holdings. This measure varies only across banks, but its value is fixed within each bank over time.

The results in Table 6 are consistent with those shown in Table 5. Results in the first column of Table 6 indicate that higher levels of excess liquidity during the period of the negative DFR are significantly and positively related to lending growth at the bank level, even after controlling for bank-level demand, borrower risk, TLTRO borrowings, bank balance sheet strength and bank as well as country-time fixed effects. The results in column 2 indicate that there is no significant relationship between initial excess liquidity holdings across banks and loan growth 
during the negative DFR period. This result is not surprising since, as shown in Figure 5, excess liquidity holdings were relatively low in the middle of 2014 and only began to grow in earnest at the commencement of the quantitative easing programme in the first quarter of 2015. Therefore, excess liquidity holdings at the initial stage would not necessarily identify banks that were most exposed to the negative DFR over time and, in particular, those that had a large increase in liquidity owing to the quantitative easing policy. The findings in columns 1 and 2 together underscore the important interaction between the two policies, insofar as they affected the opportunity cost of holding excess liquidity, through prices (DFR) and quantities (APP). The results in the second and third columns show that higher sovereign bond holdings over the period of the APP or at the inception of the APP are associated with higher loan growth over the course of the programme. The results in column 4 are strongest, indicating that holdings of sovereign bonds on a bank's balance sheet right before the central bank started to purchase these assets most clearly identifies the banks most exposed to the policy.

\section{Conclusions and macroeconomic implications}

Our findings shed light on the nature of supply and demand in determining loan growth. We show that individual banks' supply and demand are important predictors of their lending activity but that supply is more relevant during crisis periods. We find that demand for credit faced by individual banks also depends on their characteristics, such as risk profile and funding. This suggests that the assumption that firms' credit demand tends to be randomly assorted across banks may not always be valid, hence contributing to the important literature on the identification and effect of credit supply shocks. Finally, we show that (effectively controlling for loan demand) both the introduction of negative policy rates and the expanded quantitative easing stimulated loan supply in the euro area. 


\section{References}

[1] Acharya, V. V., T. Eisert, C. Eufinger, and C. W. Hirsch, 2017, Whatever it Takes: The Real Effects of Unconventional Monetary Policy, SAFE, Frankfurt, Working Paper 152.

[2] Albertazzi, U., B. Becker, and M. Boucinha, 2018, Portfolio Rebalancing and the Transmission of Large-Scale Asset Programs: Evidence from the Euro Area, European Central Bank, Frankfurt, Working Paper 2125.

[3] Altavilla, C., M. Darracq Pariès, and G. Nicoletti, 2015, Loan Supply, Credit Markets and the Euro Area Financial Crisis, European Cantral Bank, Frankfurt, Working Paper 1861.

[4] Altavilla, C., D. Giannone, and M. Lenza, 2016, "The Financial and Macroeconomic Effects of the OMT Announcements," International Journal of Central Banking 12, 29-57.

[5] Arce, O., M. García-Posada, S. Mayordomo, and S. Ongena, 2018, Adapting Lending Policies When Negative Interest Rates Hit Banks' Profits, Banco de España, Madrid, Mimeo.

[6] Berger, A. N., N. M. Miller, M. A. Petersen, R. G. Rajan, and J. C. Stein, 2005, "Does Function Follow Organizational Form? Evidence from the Lending Practices of Large and Small Banks," Journal of Financial Economics 76, 237-269.

[7] Berger A. N., and G. F. Udell, 2002, "Small Business Credit Availability and Relationship Lending: The Importance of Bank Organisational Structure," Economic Journal 112, 32-53.

[8] Bernanke, B. S., and A. S. Blinder, 1992, "The Federal Funds Rate and the Channels of Monetary Transmission," American Economic Review 82, 901-921.

[9] Billett, M.T., J. Flannery, and J.A. Garfinkel, 1995, The effect of lender identity on a borrowing firm's equity return, Journal of Finance 50, 699-718.

[10] Blaes, B., 2011, Bank-Related Loan Supply Factors During the Crisis: An Analysis Based on the German Bank Lending Survey, Bundesbank, Frankfurt, Discussion Paper 31.

[11] Bowman, D., F. Cai, S. Davies, and S. Kamin, 2015, "Quantitative easing and bank lending: Evidence from Japan," Journal of International Money and Finance 57, 15-30.

[12] Bottero Margherita, Jose-Luis Peydro, Andrea Polo, Andrea Presbitero, and Enrico Sette, 2018, "Negative Policy Rates and Bank Asset Allocations: Evidence from Italian Credit and Security Registers", mimeo.

[13] Ciccarelli, M., A. Maddaloni, and J.-L. Peydró, 2013, "Heterogeneous Transmission Mechanism: Monetary Policy and Financial Fragility in the Eurozone," Economic Policy 28, 459-512. 
[14] Ciccarelli, M., A. Maddaloni, and J.-L. Peydró, 2015, "Trusting the Bankers: A New Look at the Credit Channel of Monetary Policy," Review of Economic Dynamics 18, 979-1002.

[15] Cole, R. A., L. G. Goldberg, and L. J. White, 2004, "Cookie-Cutter versus Character: The Micro Structure of Small Business Lending by Large and Small Banks," Journal of Financial and Quantitative Analysis 39, 227-252.

[16] de Bondt, G., A. Maddaloni, J.-L. Peydró, and S. Scopel, 2010, The Euro Area Bank Lending Survey Matters: Empirical Evidence for Credit and Output Growth, European Central Bank, Frankfurt, Working Paper 1160.

[17] Degryse, H., O. De Jonghe, S. Jakovljevic, K. Mulier, and G. Schepens, 2018, Identifying Credit Supply Shocks with Bank-Firm Data: Methods and Applications, KU Leuven, Leuven, Mimeo.

[18] Degryse, H. and S. Ongena, 2005, "Distance, Lending Relationships, and Competition," Journal of Finance, 60, 231-266.

[19] Del Giovane, P., G. Eramo, and A. Nobili, 2011, "Disentangling Demand and Supply in Credit Developments: A Survey-Based Analysis for Italy," Journal of Banking and Finance $35,2719-2732$.

[20] Demiralp, S., J. Eisenschmidt, and T. Vlassopoulos, 2017, Negative Interest Rates, Excess Liquidity and Bank Business Models: Banks' Reaction to Unconventional Monetary Policy in the Euro Area, European Central Bank, Frankfurt, Mimeo.

[21] Gambacorta, L. and P.E. Mistrulli, 2004, "Does bank capital affect lending behavior?," Journal of Financial Intermediation 13, 436-457.

[22] Heider, F., F. Saidi, and G. Schepens, 2017, Life Below Zero: Bank Lending Under Negative Policy Rates European Cantral Bank, Frankfurt, Mimeo.

[23] Holmstrom, B. and J. Tirole, 1997, "Financial Intermediation, Loanable Funds, and The Real Sector," The Quarterly Journal of Economics 112, 663-691.

[24] Jiménez, G., S. Ongena, J.-L. Peydró, and J. Saurina, 2012, "Credit Supply and Monetary Policy: Identifying the Bank Balance-Sheet Channel with Loan Applications," American Economic Review 102, 2301-2326.

[25] Joyce, M., and M. Spaltro, 2014, Quantitative Easing and Bank Lending: A Panel Data Approach, Bank of England, London, Working Paper 504.

[26] Kashyap, A. K., and J. C. Stein, 2000, "What Do A Million Observations on Banks Say About the Transmission of Monetary Policy?," American Economic Review 90, 407-428. 
[27] Khwaja, A. I., and A. Mian, 2008, "Tracing the Impact of Bank Liquidity Shocks: Evidence from an Emerging Market," American Economic Review 98, 1413-1442.

[28] Kim, Moshe, Eirik Gaard Kristiansen, and Bent Vale, 2005, Endogenous product differentiation in credit markets: What do borrowers pay for?, Journal of Banking and Finance 29, 681-699.

[29] Kishan, R.P and T.P. Opiela, 2000, "Bank Size, Bank Capital, and the Bank Lending Channel," Journal of Money, Credit and Banking 32, 121-141.

[30] Lown, C., and D. P. Morgan, 2006, "The Credit Cycle and the Business Cycle: New Findings Using the Loan Officer Opinion Survey," Journal of Money, Credit and Banking $38,1575-1597$.

[31] Nucera, F., A. Lucas, J. Schaumburg, and B. Schwaab, 2017, Do Negative Interest Rates Make Banks Less Safe?, European Central Bank, Frankfurt, Working Paper 2098.

[32] Owens, R. E., and S. L. Schreft, 1995, "Identifying Credit Crunches," Contemporary Economic Policy 13, 63-77.

[33] Paravisini, D., V. Rappoport, and P. Schnabl, 2014, Comparative Advantage and Specialization in Bank Lending, London School of Economics, London, Mimeo.

[34] Paravisini, D., V. Rappoport, P. Schnabl, and D. Wolfenzon, 2015, "Dissecting the Effect of Credit Supply on Trade: Evidence from Matched Credit-Export Data," Review of Economic Studies 82, 333-359.

[35] Petersen, M. A., and R. G. Rajan, 2002, "Does Distance Still Matter? The Information Revolution in Small Business Lending," Journal of Finance 57, 2533-2570.

[36] Popov, A. A., and N. Van Horen, 2015, "Exporting Sovereign Stress: Evidence from Syndicated Bank Lending during the Euro Area Sovereign Debt Crisis," Review of Finance 19, $1825-1866$

[37] Rajan, R.G., 1992, "Insiders and outsiders: The choice between informed and arm's-length debt", Journal of Finance 47, 1367-1400.

[38] Rodnyansky, A., and O. M. Darmouni, 2017, "The Effects of Quantitative Easing on Bank Lending Behavior," Review of Financial Studies 30, 3858-3887.

[39] Schwert, M., 2018, "Bank Capital and Lending Relationships," Journal of Finance 73, 787830. 
[40] Sharpe, S.A., 1990, "Asymmetric information, bank lending and implicit contracts: A stylized model of customer relationships", Journal of Finance 45, 1069-1087.

[41] Stein, J. C., 2002, "Information Production and Capital Allocation: Decentralized versus Hierarchical Firms," Journal of Finance 57, 1891-1922. 
Figure 1: Credit conditions from the individual Bank Lending Survey (iBLS)
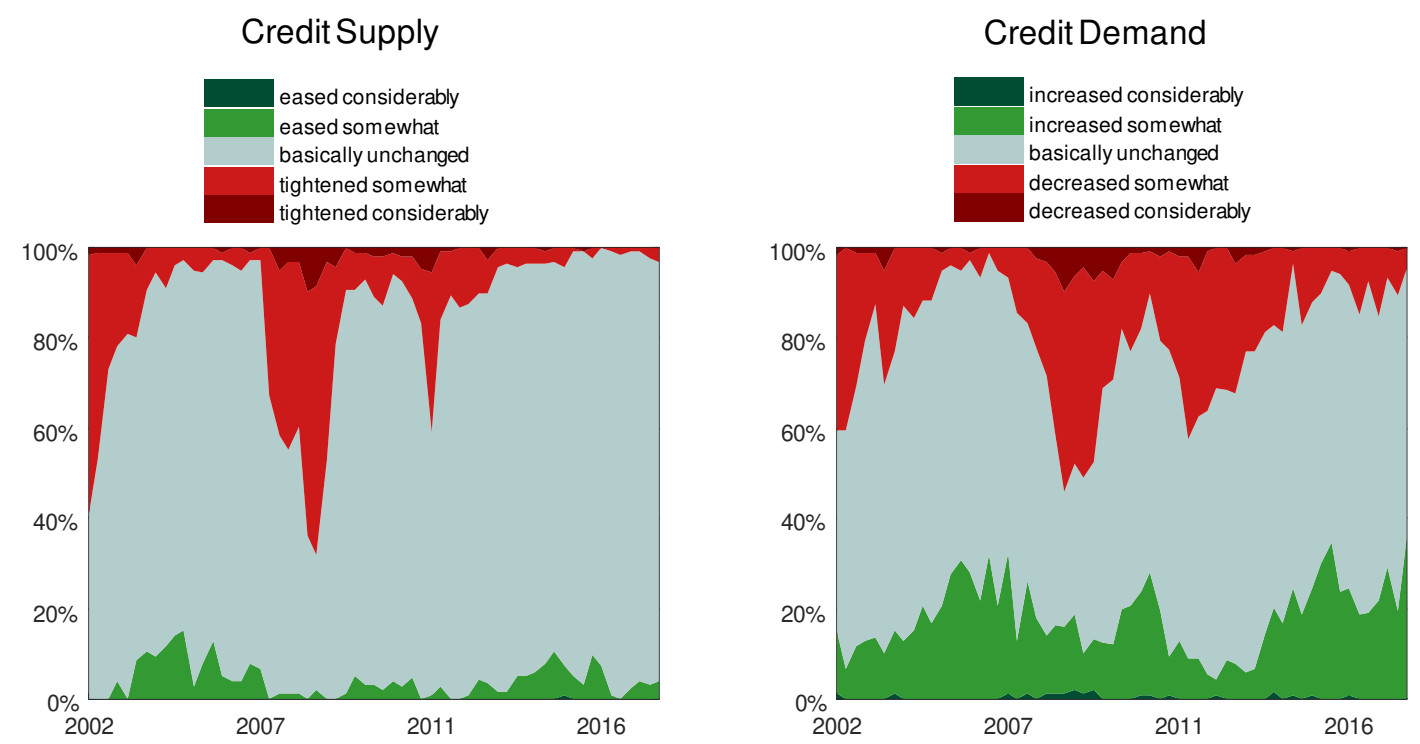

Notes: The figure displays the percent of banks reporting the indicated changes in their credit supply (i.e., credit standards) and credit demand. Source: Eurosystem iBLS. 
Figure 2: Credit conditions across regions
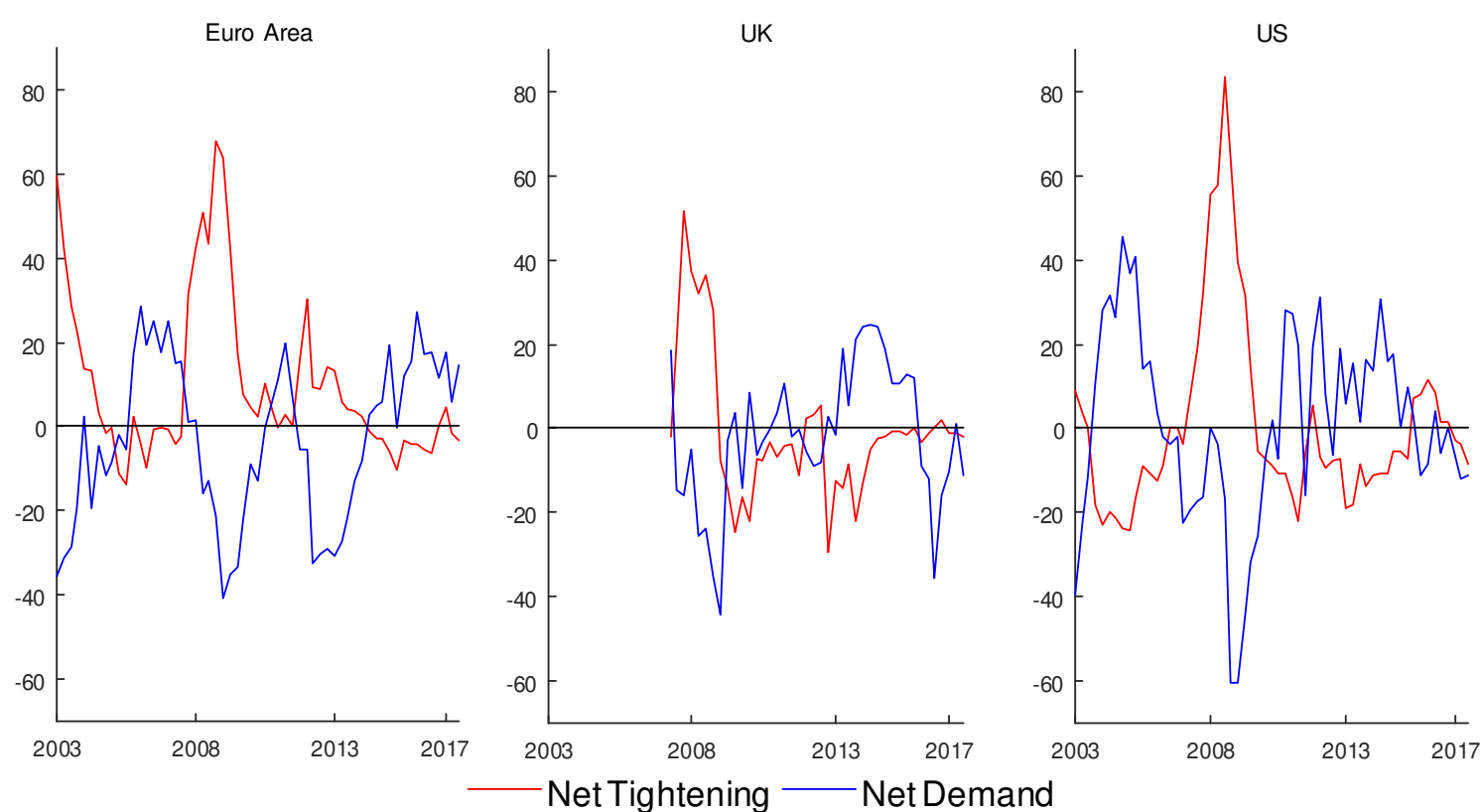

Notes: Eurosystem BLS, Bank of England Credit Conditions Survey, Federal Reserve System Senior Loan Officer Opinion Survey on Bank Lending Practices. 
Figure 3: Credit standards, demand and loans to non-financial corporations

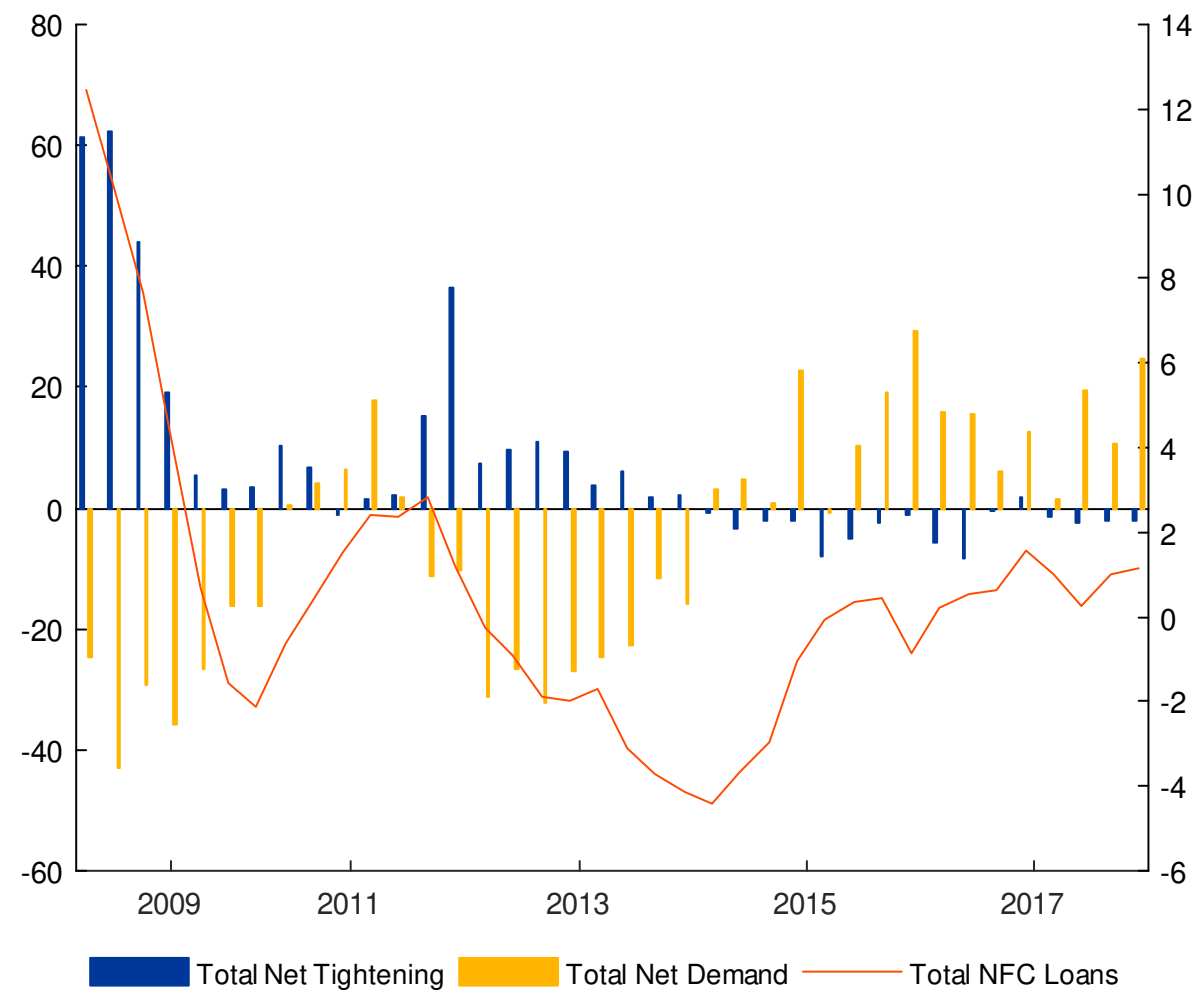

Notes: Net tightening is the percentage of banks reporting that credit standards tightened minus the percentage that reported they eased. Totals calculated using country weights. Annual loan growth calculated using iBSI data for iBLS banks. Based on the sample of banks included in iBLS. 
Figure 4: Based on the sample of banks included in iBLS

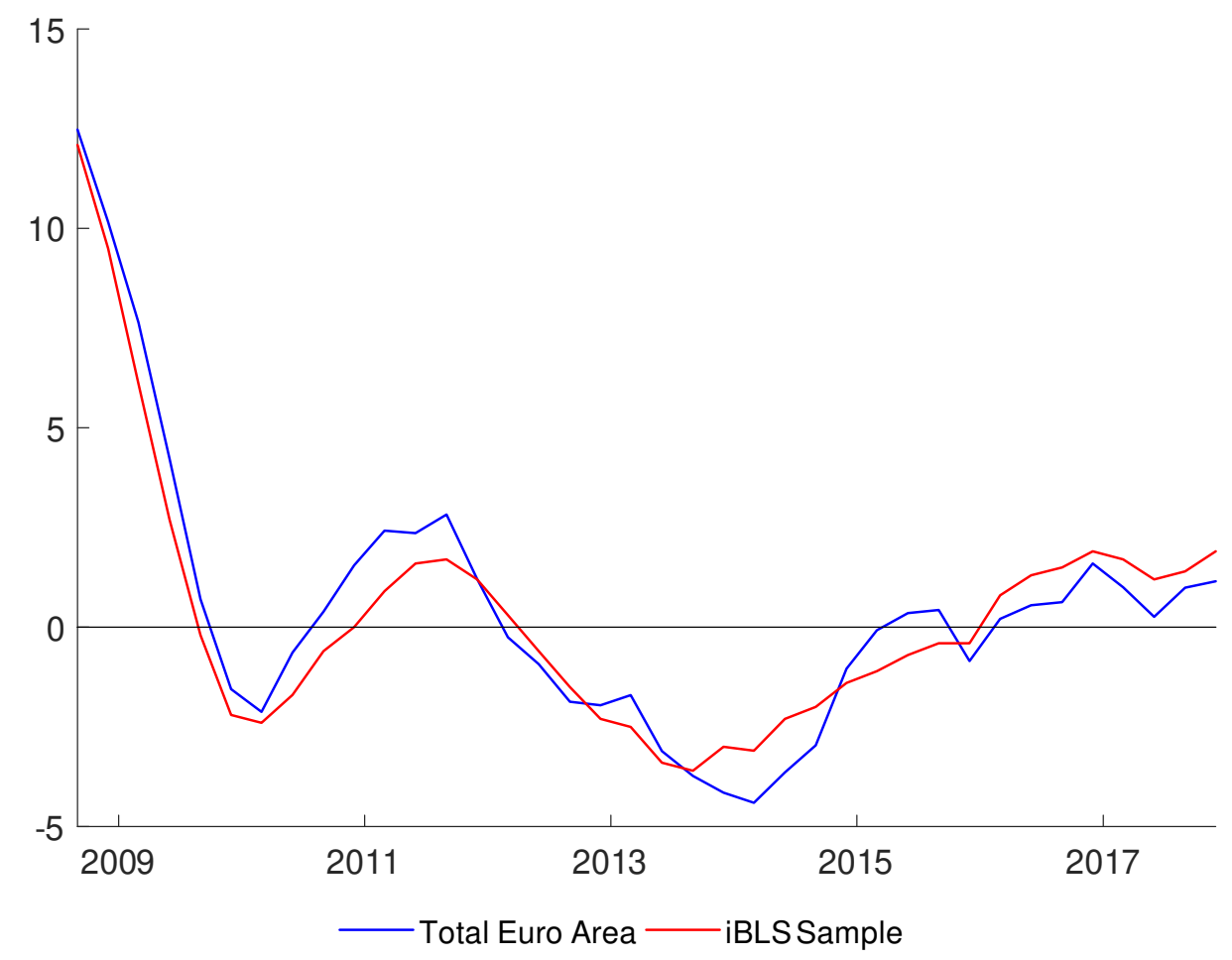

Notes: The blue line shows aggregate euro area loan growth based on ECB BSI data. The red line shows the corresponding series for the sample of banks included in the iBLS. 
Figure 5: Excess liquidity and the ECB deposit facility rate
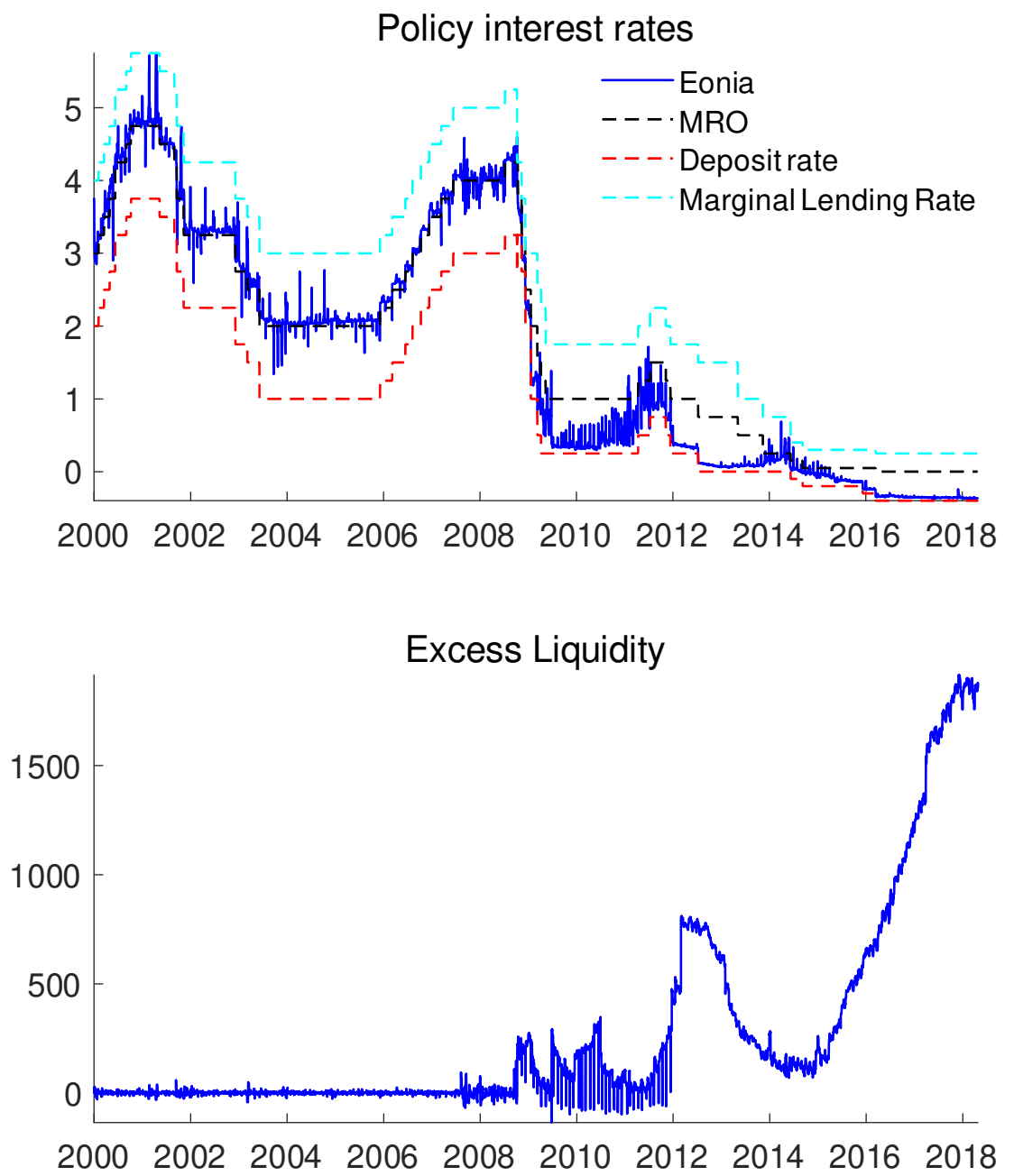

Notes: The figure displays aggregate excess liquidity of euro area banks (in euro billions) from January 2000 until April 2018 and the rate on the ECB deposit facility over the same period. 
Figure 6: Quantitative easing in the euro area

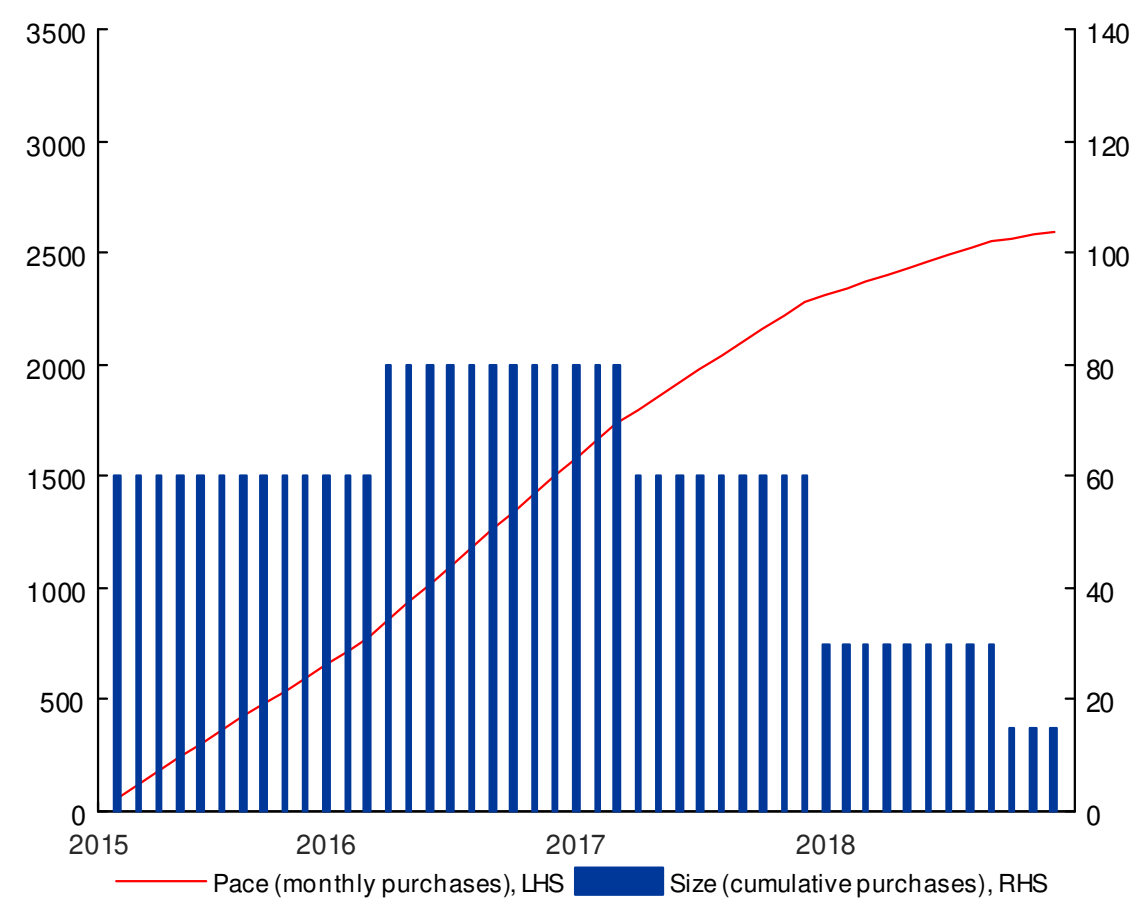

Notes: The figure displays the monthly amounts of the ECB expanded asset purchase programme and the total cumulative amounts purchased (in euro billions). 
Figure 7: Government securities and lending

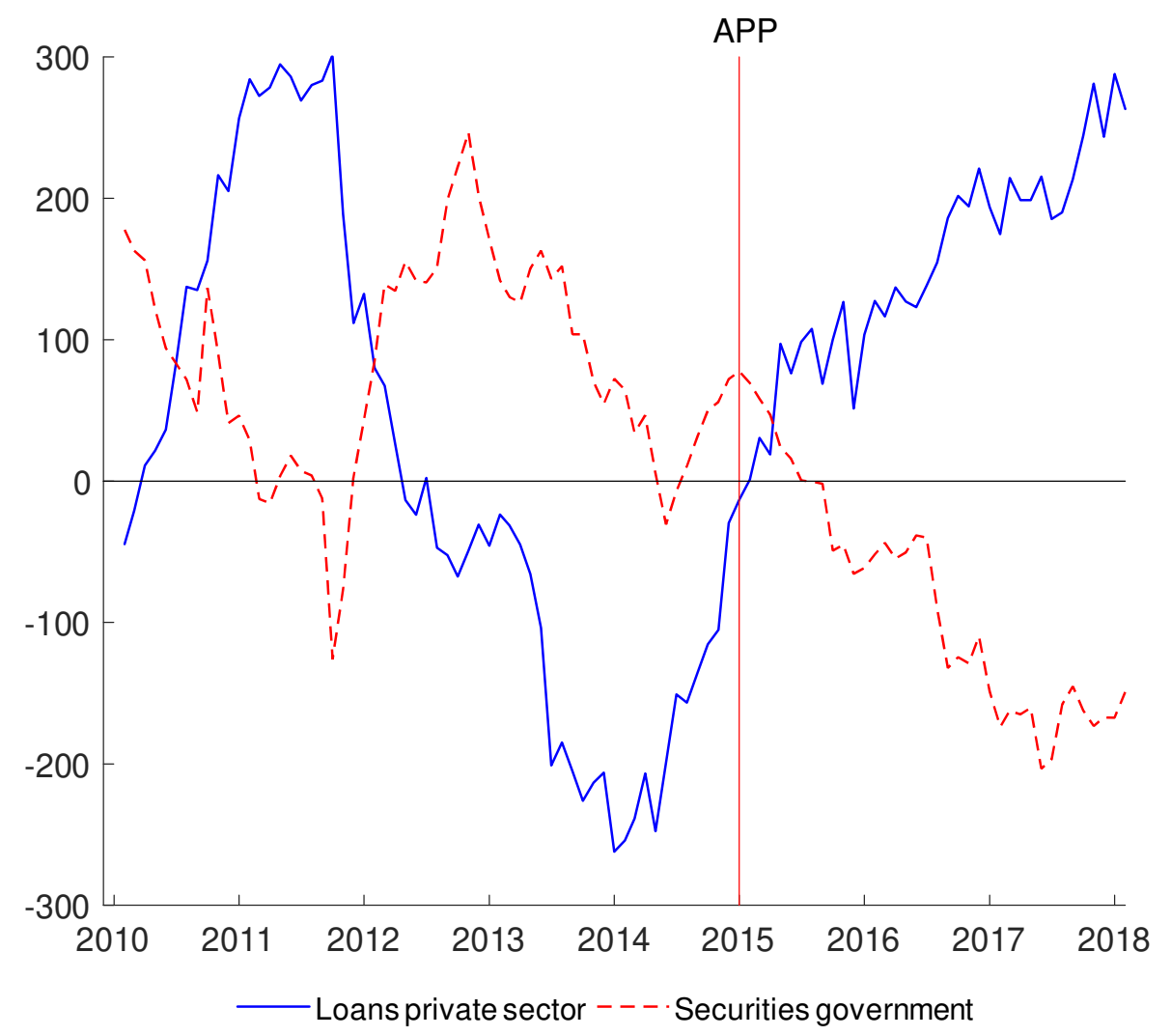

Notes:The figure displays the 12-month flows (in euro billions) of government securities and lending to the private sector for euro area banks. The vertical gridline represents the date of the announcement of the APP (January 2015). 
Figure 8: Explaining loan growth with reported supply and demand

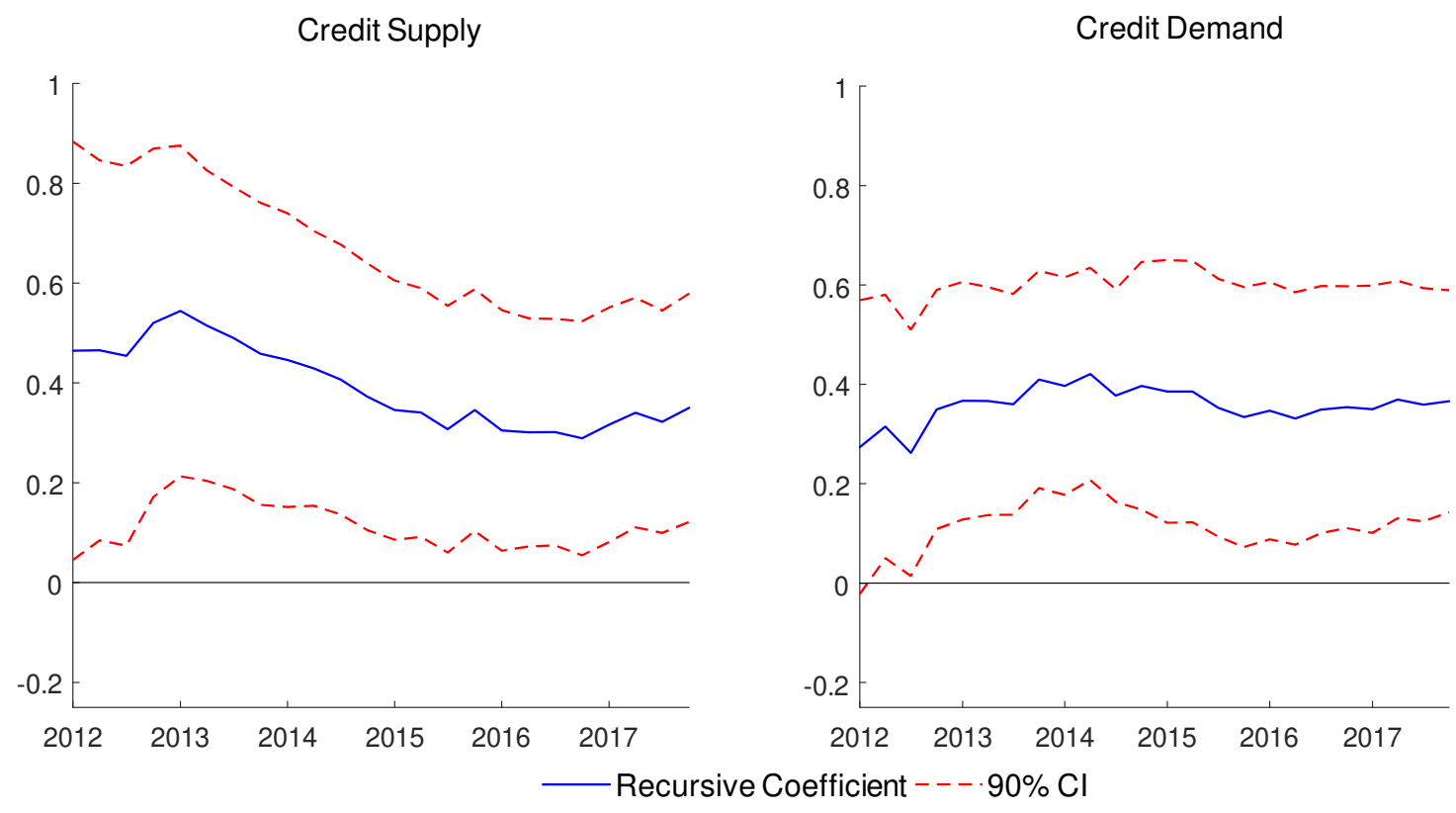

Notes: The figure displays the recursive estimates of the coefficients (and the corresponding $90 \%$ confidence intervals) of a regression of the bank-level quarterly growth rate of loans to non-financial corporation on loan supply and demand as reported by banks in the BLS for windows starting in 2007Q3 and ending in the year and quarter indicated on the x-axis (column 3 in Table 2). 
Figure 9: Difference in loan growth between treated and untreated banks in the DFR and APP.
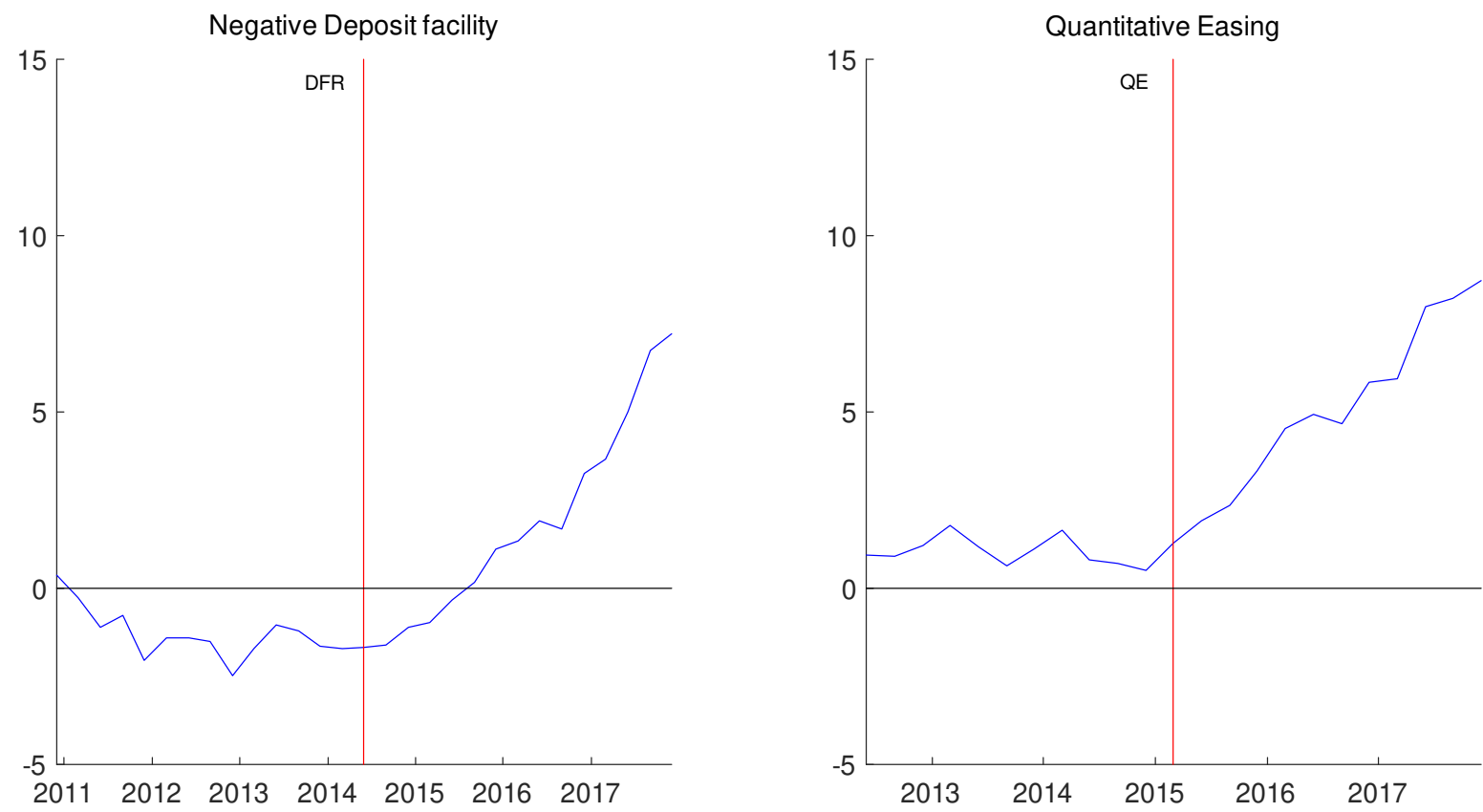

Notes: The figures display the cumulated differences in quarterly growth rates between banks in the treatment and control groups for the DFR (on the left) and APP (on the right). For the DFR, treated banks are those who on average reported that the impact of the negative interest rate policy on their net interest income was stronger. More specifically, the threshold is set at 2.5 in a scale of 1-5, which corresponds to the 75th percentile of the distribution of responses. For the APP, treated banks are those who on average reported that the APP impact on their liquidity position was more positive. More specifically, the threshold is set at 3.17 in a scale of $1-5$, which corresponds to the median of the distribution of responses. 
Table 1: Growth in observed bank lending to non-financial corporations explained by bank reported changes in credit supply and demand

\begin{tabular}{|c|c|c|c|c|}
\hline Variable name & Units & Definition & Mean & $\begin{array}{l}\text { Standard } \\
\text { deviation }\end{array}$ \\
\hline \multicolumn{5}{|l|}{ Bank credit variables } \\
\hline$\Delta$ Loans & $\%$ & $\begin{array}{l}\text { Quarterly growth rate of loan volume by bank } b \text { in country } c \text { in period } t \text { to non-financial } \\
\text { corporations }\end{array}$ & 0.58 & 3.43 \\
\hline$\Delta$ Credit supply & $1-5$ & $\begin{array}{l}\text { Over the past three months, how have your bank's credit standards as applied to the approval of loans or } \\
\text { credit lines to enterprises changed? } 1 \text { "Tightened considerably", } 2 \text { "Tightened somewhat", } 3 \\
\text { "Remained unchanged", } 4 \text { "Eased somewhat" and } 5 \text { "Eased considerably" }\end{array}$ & 2.89 & 0.44 \\
\hline$\Delta$ Credit demand & $1-5$ & $\begin{array}{l}\text { Over the past three months, how has the demand for loans or credit lines to enterprises changed at your } \\
\text { bank, apart from normal seasonal fluctuations? } 1 \text { "Decreased considerably", } 2 \text { "Decreased } \\
\text { somewhat", } 3 \text { "Remained unchanged", } 4 \text { "Increased somewhat" and } 5 \text { "Increased } \\
\text { considerably". }\end{array}$ & 2.95 & 0.67 \\
\hline Treated APP & $0-1$ & $\begin{array}{l}\text { Dummy variable equal to } 1 \text { if a banks' average response across survey dates to the } \\
\text { following BLS question is above the median response (across all banks and dates): Over } \\
\text { the past six months, has the ECB's expanded asset purchase programme affected (either } \\
\text { directly or indirectly) your bank's liquidity position? }[1=\text { considerably deteriorated; } 2= \\
\text { somewhat deteriorated; } 3=\text { no impact; } 4=\text { somewhat improved; } 5=\text { considerably } \\
\text { improved] }\end{array}$ & 0.32 & 0.47 \\
\hline Treated $D F R$ & $0-1$ & $\begin{array}{l}\text { Dummy variable equal to } 1 \text { if a banks' average response across survey dates to the } \\
\text { following BLS question is below the response at the } 75 \text { th percentile (across all banks and } \\
\text { dates): Over the past six months, how has the ECB's negative deposit facility rate, either } \\
\text { directly or indirectly, impacted on your bank's net interest income? }[1=\text { decreased } \\
\text { considerably; } 2=\text { decreased somewhat; } 3=\text { no impact; } 4=\text { increased somewhat; } 5= \\
\text { increased considerably] }\end{array}$ & 0.73 & 0.45 \\
\hline Treated $A P P$ and $D F R$ & $0-1$ & $\begin{array}{l}\text { Dummy variable equal to } 1 \text { if Treated } A P P=1 \text { and Treated } D F R=1 \text { and equal to } 0 \text { if } \\
\text { Treated } A P P=0 \text { and Treated } D F R=0 .\end{array}$ & 0.55 & 0.50 \\
\hline Post APP & $0-1$ & Dummy equal to 1 from $2015 \mathrm{Q} 1$ until $2017 \mathrm{Q} 4$ and 0 otherwise & & \\
\hline Post DFR & $0-1$ & Dummy equal to 1 from $2014 \mathrm{Q} 3$ until $2017 \mathrm{Q} 4$ and 0 otherwise & & \\
\hline$\triangle \mathrm{CDS}$ & Basis points & Change in CDS spread of bank $b$ in country $c$ in period $t$ & 1.68 & 77.68 \\
\hline Borrower risk & $1-5$ & $\begin{array}{l}\text { Over the past three months, how have Industry or firm-specific situation and } \\
\text { outlook/borrower's creditworthiness affected your bank's credit standards as applied to } \\
\text { the approval of loans or credit lines to enterprises? } 1 \text { "contributed considerably to } \\
\text { tightening", } 2 \text { "contributed somewhat to tightening ", } 3 \text { "Basically unchanged", } 4 \\
\text { "contributed somewhat to easing", } 5 \text { "contributed considerably to easing" of credit } \\
\text { standards. Inverted so that higher numbers represent higher borrower risk. }\end{array}$ & -2.82 & 0.50 \\
\hline Size & & Log of main assets & 10.66 & 1.45 \\
\hline Liquidity & Ratio & $\begin{array}{l}\text { Liquid assets to main assets ratio. Liquid assets are defined as loans to MFIs, and debt } \\
\text { securities holdings. }\end{array}$ & 0.34 & 0.19 \\
\hline Leverage ratio & Ratio & Capital and reserves to main assets. & 0.09 & 0.06 \\
\hline TLTRO & $\%$ & TLTRO borrowings as a share of main assets & 0.60 & 2.02 \\
\hline Excess Liquidity & Ratio & Excess liquidity holdings as a share of main assets & 0.02 & 0.04 \\
\hline Sov bond holdings & Ratio & Sovereign bond holdings as a share of main assets & 0.06 & 0.06 \\
\hline Excess Liquidity (June 2014) & Ratio & Excess liquidity holdings as a share of main assets (Level fixed at June 2014 for each bank) & 0.01 & 0.02 \\
\hline Sov bond holdings (Dec 2014) & Ratio & $\begin{array}{l}\text { Sovereign bond holdings as a share of main assets (level fixed at December } 2014 \text { for each } \\
\text { bank) }\end{array}$ & 0.07 & 0.06 \\
\hline \multicolumn{5}{|l|}{ Monetary polity indicator } \\
\hline$\Delta$ Euribor & $\%$ & Change in 3-month Euribor & -0.11 & 0.47 \\
\hline
\end{tabular}

Notes: The table displays the variable names, units, definitions, summary statistics and data sources. iBSI is the individual banks Balance Sheet Items Statistics from the ECB. iBLS are individual banks' responses to the ECB Bank Lending Survery. ECB SDW is the ECB Statistical Data Warehouse. 
Table 2: Growth in observed bank lending to non-financial corporations explained by bank reported changes in credit supply and demand

\begin{tabular}{|c|c|c|c|}
\hline Dependent variable: & $\Delta$ Loans $_{\mathrm{b}, \mathrm{c}, \mathrm{t}}$ & $\Delta$ Loans $_{\mathrm{b}, \mathrm{c}, \mathrm{t}}$ & $\Delta$ Loans $_{\mathrm{b}, \mathrm{c}, \mathrm{t}}$ \\
\hline$\Delta$ Credit supply $y_{b, c, t}$ & $\begin{array}{c}0.566^{* * *} \\
(0.109)\end{array}$ & $\begin{array}{c}0.305^{* * *} \\
(0.110)\end{array}$ & $\begin{array}{l}0.350^{* *} \\
(0.139)\end{array}$ \\
\hline$\Delta$ Credit demand $\mathrm{b}_{\mathrm{b}, \mathrm{c}, \mathrm{t}}$ & $\begin{array}{l}0.464 * * * \\
(0.0886)\end{array}$ & $\begin{array}{c}0.453^{* * *} \\
(0.105)\end{array}$ & $\begin{array}{c}0.366^{* * *} \\
(0.136)\end{array}$ \\
\hline$\Delta$ Loans $_{\mathrm{b}, \mathrm{c}, \mathrm{t}-1}$ & $\begin{array}{c}0.0704 * * * \\
(0.0243)\end{array}$ & $\begin{array}{c}0.0131 \\
(0.0263)\end{array}$ & $\begin{array}{l}-0.0162 \\
(0.0341)\end{array}$ \\
\hline$\Delta$ Loans $_{\mathrm{b}, \mathrm{c}, \mathrm{t}-2}$ & $\begin{array}{l}0.159 * * * \\
(0.0208)\end{array}$ & $\begin{array}{l}0.105^{* * *} \\
(0.0209)\end{array}$ & $\begin{array}{c}0.0918^{* * *} \\
(0.0278)\end{array}$ \\
\hline$\Delta$ Loans $_{\mathrm{b}, \mathrm{c}, \mathrm{t}-3}$ & $\begin{array}{c}0.0767^{* * *} \\
(0.0248)\end{array}$ & $\begin{array}{c}0.0295 \\
(0.0263)\end{array}$ & $\begin{array}{l}0.0479 * \\
(0.0288)\end{array}$ \\
\hline$\Delta$ Loans $_{\mathrm{b}, \mathrm{c}, \mathrm{t}-4}$ & $\begin{array}{l}0.217^{* * *} \\
(0.0249)\end{array}$ & $\begin{array}{l}0.175^{* * *} \\
(0.0261)\end{array}$ & $\begin{array}{l}0.179 * * * \\
(0.0291)\end{array}$ \\
\hline $\begin{array}{l}\text { Bank fixed effects } \\
\text { Country-time fixed effects }\end{array}$ & $\begin{array}{l}\text { No } \\
\text { No }\end{array}$ & $\begin{array}{l}\text { Yes } \\
\text { No }\end{array}$ & $\begin{array}{l}\text { Yes } \\
\text { Yes }\end{array}$ \\
\hline Number of observations & 3308 & 3308 & 3308 \\
\hline Number of banks & 107 & 107 & 107 \\
\hline $\mathrm{R}^{2}$ & 0.153 & 0.201 & 0.360 \\
\hline
\end{tabular}

Notes: The table displays the estimates of the coefficients in equation (1). The dependent variable is the quarterly bank level growth rate of loans to non-financial corporations during the period 2007Q4-2017Q4. Coefficients are listed in the first row, robust standard errors that are corrected for clustering at the bank level are reported in the row below, and the corresponding significance levels are indicated with stars. "Yes" indicates that the set of characteristics or fixed effects is included. "No" indicates that the set of characteristics or fixed effects is not included. ${ }^{* * *}$ Significant at $1 \%$, ** significant at $5 \%,{ }^{*}$ significant at $10 \%$. 
Table 3: Bank reported changes in credit supply and demand explained by bank balance sheet strength and monetary conditions

\begin{tabular}{|c|c|c|c|c|}
\hline \multirow[t]{2}{*}{ Dependent variable: } & \multicolumn{2}{|c|}{$\Delta$ Credit supply $\mathrm{b}_{\mathrm{b}, \mathrm{c}, \mathrm{t}}$} & \multicolumn{2}{|c|}{$\Delta$ Credit demand $\mathrm{b}_{\mathrm{b}, \mathrm{c}, \mathrm{t}}$} \\
\hline & $\begin{array}{c}-0.000554^{* *} \\
(0.000219)\end{array}$ & $\begin{array}{c}-0.000499 * * * \\
(0.000178)\end{array}$ & $\begin{array}{c}-0.000782^{* * *} \\
(0.000272)\end{array}$ & $\begin{array}{c}-0.000757^{* * *} \\
(0.000258)\end{array}$ \\
\hline$\Delta$ Euribor $_{\mathrm{t}-1} \times \Delta \mathrm{CDS}_{\mathrm{b}, \mathrm{c}, \mathrm{t}-1}$ & $\begin{array}{c}-0.000960^{*} \\
(0.000493)\end{array}$ & $\begin{array}{c}-0.000847^{* *} \\
(0.000408)\end{array}$ & $\begin{array}{c}-0.00147^{* * *} \\
(0.000527)\end{array}$ & $\begin{array}{c}-0.00142 * * \\
(0.000551)\end{array}$ \\
\hline Borrower risk $k_{b, c, t}$ & & $\begin{array}{c}-0.331 \text { *** } \\
(0.0327)\end{array}$ & & $\begin{array}{c}-0.199 \text { *** } \\
(0.0357)\end{array}$ \\
\hline Dependent Variable $\mathrm{b}_{\mathrm{b}, \mathrm{c}, \mathrm{t}-1}$ & $\begin{array}{c}0.216^{* * *} \\
(0.0345)\end{array}$ & $\begin{array}{c}0.167 * * * \\
(0.0334)\end{array}$ & $\begin{array}{c}0.240 * * * \\
(0.0265)\end{array}$ & $\begin{array}{c}0.231 * * * \\
(0.0272)\end{array}$ \\
\hline Dependent Variable $e_{b, c, t-2}$ & $\begin{array}{c}0.0410 \\
(0.0267)\end{array}$ & $\begin{array}{c}0.0183 \\
(0.0274)\end{array}$ & $\begin{array}{c}0.109 * * * \\
(0.0275)\end{array}$ & $\begin{array}{c}0.111 * * * \\
(0.0283)\end{array}$ \\
\hline Dependent Variable $e_{b, c, t-3}$ & $\begin{array}{l}-0.00221 \\
(0.0197)\end{array}$ & $\begin{array}{l}-0.0168 \\
(0.0173)\end{array}$ & $\begin{array}{l}0.00943 \\
(0.0231)\end{array}$ & $\begin{array}{l}0.00349 \\
(0.0231)\end{array}$ \\
\hline Dependent Variable $_{\mathrm{b}, \mathrm{c},-4}$ & $\begin{array}{l}-0.0269 \\
(0.0273)\end{array}$ & $\begin{array}{l}-0.0235 \\
(0.0238)\end{array}$ & $\begin{array}{l}0.00954 \\
(0.0226)\end{array}$ & $\begin{array}{l}0.00956 \\
(0.0214)\end{array}$ \\
\hline Bank fixed effects & Yes & Yes & Yes & Yes \\
\hline Country-time fixed effects & Yes & Yes & Yes & Yes \\
\hline Number of observations & 2662 & 2659 & 2642 & 2639 \\
\hline Number of banks & 90 & 90 & 90 & 90 \\
\hline $\mathrm{R}^{2}$ & 0.554 & 0.616 & 0.499 & 0.509 \\
\hline
\end{tabular}

Notes: The table displays the estimates of the coefficients in equations (2) and (3). The dependent variables are the bank reported changes in Credit supply and Credit demand during the period 2007Q4-2017Q4. The bank-level Balance sheet constraints are measured at the change in the bank's CDS spread. Coefficients are listed in the first row, robust standard errors that are corrected for clustering at the bank level are reported in the row below, and the corresponding significance levels are indicated with stars. "Yes" indicates that the set of characteristics or fixed effects is included. "No" indicates that the set of characteristics or fixed effects is not included. *** Significant at 1\%, ** significant at $5 \%,{ }^{*}$ significant at $10 \%$. 
Table 4: Bank reported changes in credit demand explained by various measures of bank balance sheet strength and monetary conditions

\begin{tabular}{|c|c|c|c|c|}
\hline Dependent variable: & \multicolumn{4}{|c|}{$\Delta$ Credit demand ${ }_{b, c, t}$} \\
\hline Bank characteristic $\mathrm{b}_{\mathrm{b}, \mathrm{t}, \mathrm{t}-1}$ & $\begin{array}{c}-0.000757^{* * *} \\
(0.000258)\end{array}$ & $\begin{array}{c}-0.0929^{* *} \\
(0.0406)\end{array}$ & $\begin{array}{l}-0.00431 \\
(0.0127)\end{array}$ & $\begin{array}{c}-0.0180^{*} \\
(0.00948)\end{array}$ \\
\hline Borrower risk $k_{b, c, t}$ & $\begin{array}{c}-0.199 * * * \\
(0.0357)\end{array}$ & $\begin{array}{c}-0.260 * * * \\
(0.0637)\end{array}$ & $\begin{array}{c}-0.239 * * * \\
(0.0620)\end{array}$ & $\begin{array}{c}-0.199^{* * *} \\
(0.0312)\end{array}$ \\
\hline$\Delta$ Credit demand $\mathrm{b}_{\mathrm{b}, \mathrm{c}, \mathrm{-}-1}$ & $\begin{array}{c}0.231 * * * \\
(0.0272)\end{array}$ & $\begin{array}{c}0.277^{* * *} \\
(0.0343)\end{array}$ & $\begin{array}{c}0.203^{* * *} \\
(0.0439)\end{array}$ & $\begin{array}{c}0.238^{* * *} \\
(0.0228)\end{array}$ \\
\hline$\Delta$ Credit demand ${ }_{b, c, t-4}$ & $\begin{array}{l}0.00956 \\
(0.0214)\end{array}$ & $\begin{array}{l}-0.0409 \\
(0.0278)\end{array}$ & $\begin{array}{c}0.0150 \\
(0.0290)\end{array}$ & $\begin{array}{c}0.0179 \\
(0.0208)\end{array}$ \\
\hline Bank fixed effects & Yes & Yes & Yes & Yes \\
\hline Country-time fixed effects & Yes & Yes & Yes & Yes \\
\hline $\begin{array}{l}\text { Number of observations } \\
\text { Number of banks }\end{array}$ & $\begin{array}{c}2639 \\
90\end{array}$ & $\begin{array}{c}677 \\
29\end{array}$ & $\begin{array}{c}1109 \\
45\end{array}$ & $\begin{array}{c}3775 \\
118\end{array}$ \\
\hline $\mathrm{R}^{2}$ & 0.509 & 0.598 & 0.507 & 0.467 \\
\hline
\end{tabular}

Notes: The table displays the estimates of the coefficients in equation (3). The dependent variable is the bank reported change in Credit demand during the period 2007Q4-2017Q4. Coefficients are listed in the first row, robust standard errors that are corrected for clustering at the bank level are reported in the row below, and the corresponding significance levels are indicated with stars. "Yes" indicates that the set of characteristics or fixed effects is included. "No" indicates that the set of characteristics or fixed effects is not included. ${ }^{* *}$ Significant at $1 \%,{ }^{* *}$ significant at $5 \%, *$ significant at $10 \%$. 
Table 5: Impact of non-standard measures on bank lending

\begin{tabular}{|c|c|c|c|c|c|c|c|c|c|}
\hline \multirow{2}{*}{$\frac{\text { Policy measure: }}{\left(\text { Treated }_{\mathrm{b}, \mathrm{c}}\right) \times\left(\text { Post }_{\mathrm{t}}\right)}$} & \multicolumn{3}{|c|}{ DFR } & \multicolumn{3}{|c|}{ APP } & \multicolumn{3}{|c|}{ DFR and APP } \\
\hline & $\begin{array}{c}0.567^{* * *} \\
(0.215)\end{array}$ & $\begin{array}{c}0.601 * * \\
(0.258)\end{array}$ & $\begin{array}{c}0.865^{* * *} \\
(0.292)\end{array}$ & $\begin{array}{c}0.561 * * \\
(0.237)\end{array}$ & $\begin{array}{c}0.709 * * \\
(0.280)\end{array}$ & $\begin{array}{l}0.494^{*} \\
(0.286)\end{array}$ & $\begin{array}{c}1.088^{* * *} \\
(0.319)\end{array}$ & $\begin{array}{c}1.267^{* * *} \\
(0.380)\end{array}$ & $\begin{array}{c}1.092^{* *} \\
(0.426)\end{array}$ \\
\hline Post $_{\mathrm{t}}$ & $\begin{array}{l}0.0103 \\
(0.169)\end{array}$ & $\begin{array}{l}0.0563 \\
(0.209)\end{array}$ & & $\begin{array}{l}0.347^{*} \\
(0.177)\end{array}$ & $\begin{array}{c}0.440^{* *} \\
(0.208)\end{array}$ & & $\begin{array}{c}-0.00417 \\
(0.198)\end{array}$ & $\begin{array}{c}0.158 \\
(0.256)\end{array}$ & \\
\hline Treated $_{b, c, t}$ & $\begin{array}{l}-0.152 \\
(0.160)\end{array}$ & & & $\begin{array}{l}-0.130 \\
(0.145)\end{array}$ & & & $\begin{array}{l}-0.303 \\
(0.236)\end{array}$ & & \\
\hline$\Delta$ Demand $_{\mathrm{b}, \mathrm{c}, \mathrm{t}}$ & $\begin{array}{c}0.401 * * * \\
(0.0984)\end{array}$ & $\begin{array}{c}0.400^{* * *} \\
(0.115)\end{array}$ & $\begin{array}{c}0.358^{* * *} \\
(0.133)\end{array}$ & $\begin{array}{c}0.357 * * * \\
(0.0971)\end{array}$ & $\begin{array}{c}0.334 * * * \\
(0.114)\end{array}$ & $\begin{array}{c}0.325^{* *} \\
(0.136)\end{array}$ & $\begin{array}{c}0.423 * * * \\
(0.116)\end{array}$ & $\begin{array}{c}0.387^{* * *} \\
(0.120)\end{array}$ & $\begin{array}{c}0.257 \\
(0.160)\end{array}$ \\
\hline Borrower risk $\mathrm{b}, \mathrm{c}, \mathrm{t}$ & $\begin{array}{c}-0.292^{* * *} \\
(0.0978)\end{array}$ & $\begin{array}{l}-0.112 \\
(0.108)\end{array}$ & $\begin{array}{l}-0.172 \\
(0.130)\end{array}$ & $\begin{array}{c}-0.294 * * * \\
(0.0948)\end{array}$ & $\begin{array}{l}-0.134 \\
(0.106)\end{array}$ & $\begin{array}{l}-0.191 \\
(0.132)\end{array}$ & $\begin{array}{c}-0.310^{* *} \\
(0.153)\end{array}$ & $\begin{array}{l}-0.139 \\
(0.147)\end{array}$ & $\begin{array}{l}-0.196 \\
(0.212)\end{array}$ \\
\hline Leverage $_{b, c, t-1}$ & $\begin{array}{c}-4.537^{* * *} \\
(1.038)\end{array}$ & $\begin{array}{c}-6.049 * * * \\
(2.225)\end{array}$ & $\begin{array}{c}0.352 \\
(3.234)\end{array}$ & $\begin{array}{c}-4.532^{* * *} \\
(1.090)\end{array}$ & $\begin{array}{c}-6.214^{* *} \\
(2.450)\end{array}$ & $\begin{array}{l}-0.272 \\
(3.227)\end{array}$ & $\begin{array}{c}-6.728^{* * *} \\
(2.012)\end{array}$ & $\begin{array}{c}-8.383^{*} \\
(4.175)\end{array}$ & $\begin{array}{l}-1.905 \\
(7.024)\end{array}$ \\
\hline Size $_{b, c, t-1}$ & $\begin{array}{c}-0.108^{* *} \\
(0.0425)\end{array}$ & $\begin{array}{c}-1.145^{* * *} \\
(0.338)\end{array}$ & $\begin{array}{c}-1.332 * * * \\
(0.444)\end{array}$ & $\begin{array}{c}-0.103 * * \\
(0.0438)\end{array}$ & $\begin{array}{c}-1.170^{* * *} \\
(0.356)\end{array}$ & $\begin{array}{c}-1.149 * * * \\
(0.422)\end{array}$ & $\begin{array}{c}-0.132^{*} \\
(0.0675)\end{array}$ & $\begin{array}{c}-1.429 * * * \\
(0.532)\end{array}$ & $\begin{array}{l}-1.032 \\
(0.732)\end{array}$ \\
\hline Liquidity $_{\mathrm{b}, \mathrm{c}, \mathrm{t}-1}$ & $\begin{array}{l}-0.589 \\
(0.433)\end{array}$ & $\begin{array}{c}1.513 \\
(1.236)\end{array}$ & $\begin{array}{l}2.679 * \\
(1.402)\end{array}$ & $\begin{array}{l}-0.575 \\
(0.450)\end{array}$ & $\begin{array}{c}1.462 \\
(1.246)\end{array}$ & $\begin{array}{l}2.552^{*} \\
(1.388)\end{array}$ & $\begin{array}{l}-0.748 \\
(0.537)\end{array}$ & $\begin{array}{c}3.337^{* *} \\
(1.443)\end{array}$ & $\begin{array}{c}4.355^{* *} \\
(1.699)\end{array}$ \\
\hline TLTRO $_{b, c, t-1}$ & $\begin{array}{c}0.0191 \\
(0.0180)\end{array}$ & $\begin{array}{c}0.0392 \\
(0.0277)\end{array}$ & $\begin{array}{l}-0.0131 \\
(0.0389)\end{array}$ & $\begin{array}{c}-0.00504 \\
(0.0228)\end{array}$ & $\begin{array}{c}-0.00844 \\
(0.0336)\end{array}$ & $\begin{array}{r}-0.00307 \\
(0.0388)\end{array}$ & $\begin{array}{c}0.0193 \\
(0.0312)\end{array}$ & $\begin{array}{c}0.0198 \\
(0.0455)\end{array}$ & $\begin{array}{c}0.0150 \\
(0.0534)\end{array}$ \\
\hline Dependent Variable $e_{\mathrm{b}, \mathrm{c}, \mathrm{t}-1}$ & $\begin{array}{c}0.0533^{* *} \\
(0.0257)\end{array}$ & $\begin{array}{l}0.00300 \\
(0.0276)\end{array}$ & $\begin{array}{l}-0.0225 \\
(0.0339)\end{array}$ & $\begin{array}{c}0.0651 * * * \\
(0.0240)\end{array}$ & $\begin{array}{c}0.0127 \\
(0.0255)\end{array}$ & $\begin{array}{c}-0.00719 \\
(0.0301)\end{array}$ & $\begin{array}{c}0.0303 \\
(0.0330)\end{array}$ & $\begin{array}{l}-0.0266 \\
(0.0299)\end{array}$ & $\begin{array}{l}-0.0287 \\
(0.0324)\end{array}$ \\
\hline Dependent Variable $e_{\mathrm{b}, \mathrm{c}, \mathrm{t}-2}$ & $\begin{array}{c}0.141 * * * \\
(0.0220)\end{array}$ & $\begin{array}{c}0.0945^{* * *} \\
(0.0222)\end{array}$ & $\begin{array}{c}0.0852^{* * *} \\
(0.0274)\end{array}$ & $\begin{array}{c}0.128 * * * \\
(0.0221)\end{array}$ & $\begin{array}{c}0.0800^{* * *} \\
(0.0224)\end{array}$ & $\begin{array}{c}0.0760 * * * \\
(0.0266)\end{array}$ & $\begin{array}{c}0.114^{* * *} \\
(0.0255)\end{array}$ & $\begin{array}{c}0.0588^{* * *} \\
(0.0210)\end{array}$ & $\begin{array}{c}0.0357 \\
(0.0305)\end{array}$ \\
\hline Dependent Variable $e_{b, c, t-3}$ & $\begin{array}{c}0.0647^{* *} \\
(0.0254)\end{array}$ & $\begin{array}{c}0.0234 \\
(0.0267)\end{array}$ & $\begin{array}{c}0.0437 \\
(0.0289)\end{array}$ & $\begin{array}{c}0.0826^{* * *} \\
(0.0205)\end{array}$ & $\begin{array}{c}0.0408^{*} \\
(0.0215)\end{array}$ & $\begin{array}{c}0.0627^{* *} \\
(0.0248)\end{array}$ & $\begin{array}{c}0.0526 * \\
(0.0291)\end{array}$ & $\begin{array}{l}0.00425 \\
(0.0269)\end{array}$ & $\begin{array}{c}0.0195 \\
(0.0352)\end{array}$ \\
\hline Dependent Variable $e_{\mathrm{b}, \mathrm{c}, \mathrm{t}-4}$ & $\begin{array}{c}0.211^{* * *} \\
(0.0255)\end{array}$ & $\begin{array}{c}0.173^{* * *} \\
(0.0267)\end{array}$ & $\begin{array}{c}0.176^{* * *} \\
(0.0289)\end{array}$ & $\begin{array}{c}0.196^{* * *} \\
(0.0257)\end{array}$ & $\begin{array}{c}0.157^{* * *} \\
(0.0274)\end{array}$ & $\begin{array}{c}0.168^{* * *} \\
(0.0293)\end{array}$ & $\begin{array}{c}0.199 * * * \\
(0.0381)\end{array}$ & $\begin{array}{c}0.153^{* * *} \\
(0.0410)\end{array}$ & $\begin{array}{c}0.140^{* * *} \\
(0.0428)\end{array}$ \\
\hline Bank fixed effects & No & Yes & Yes & No & Yes & Yes & No & Yes & Yes \\
\hline$\frac{\text { Country-time fixed effects }}{\text { Number of observations }}$ & $\frac{\text { No }}{3304}$ & $\frac{\text { No }}{3304}$ & $\frac{\text { Yes }}{3304}$ & $\frac{\text { No }}{3196}$ & $\frac{\text { No }}{3196}$ & $\frac{\text { Yes }}{3196}$ & $\frac{\text { No }}{1553}$ & No & $\begin{array}{c}\text { Yes } \\
1553\end{array}$ \\
\hline Number of banks & 106 & 106 & 106 & 103 & 103 & 103 & 49 & 49 & 49 \\
\hline $\mathrm{R}^{2}$ & 0.165 & 0.212 & 0.368 & 0.165 & 0.214 & 0.367 & 0.162 & 0.213 & 0.385 \\
\hline
\end{tabular}

Notes: The table displays the estimates of the coefficients in equations (2) and (3). The dependent variable is the quarterly growth rate of loans to the non-financial corporations during the period 2007Q4-2017Q4. For the DFR, treated banks are those who on average reported that the impact of the negative interest rate policy on their net interest margin was stronger. For the APP, treated banks are those who on average reported that the APP impact on their liquidity position was more positive. The model includes 4 lags of the dependent variable (not shown). Robust standard errors clustered at the bank level and reported in brackets. ${ }^{* * *}$ Significant at $1 \%$, ** significant at $5 \%, *$ significant at $10 \%$. 
Table 6: Robustness: alternative balance sheet measures to proxy for the impact of non-standard measure

\begin{tabular}{|c|c|c|c|c|}
\hline Balance sheet measure: & Excess liquidity & Excess liquidity (June 2014) & Sovereign bond holdings & $\begin{array}{l}\text { Sovereign bond holdings } \\
\text { (December 2014) }\end{array}$ \\
\hline (Balance sheet measure $\left.\mathrm{b}, \mathrm{c}, \mathrm{t}-\mathrm{1}_{1}\right) \mathrm{x}\left(\right.$ Post $\left._{\mathrm{t}}\right)$ & $\begin{array}{c}29.58^{* * *} \\
(7.773)\end{array}$ & $\begin{array}{l}-13.34 \\
(39.71)\end{array}$ & $\begin{array}{l}5.612^{*} \\
(3.180)\end{array}$ & $\begin{array}{l}6.023^{* *} \\
(2.649)\end{array}$ \\
\hline Balance sheet measure $e_{b, c, t-1}$ & $\begin{array}{c}-25.56^{* * *} \\
(7.595)\end{array}$ & & $\begin{array}{l}-3.567 \\
(3.560)\end{array}$ & \\
\hline$\Delta$ Demand $_{b, c, t}$ & $\begin{array}{c}0.312^{* *} \\
(0.132)\end{array}$ & $\begin{array}{c}0.304 * * \\
(0.134)\end{array}$ & $\begin{array}{c}0.352^{* * *} \\
(0.133)\end{array}$ & $\begin{array}{c}0.344^{* *} \\
(0.133)\end{array}$ \\
\hline Borrower risk $k_{b, c, t}$ & $\begin{array}{l}-0.238 \\
(0.148)\end{array}$ & $\begin{array}{l}-0.193 \\
(0.148)\end{array}$ & $\begin{array}{l}-0.182 \\
(0.131)\end{array}$ & $\begin{array}{l}-0.179 \\
(0.130)\end{array}$ \\
\hline Leverage $_{\mathrm{b}, \mathrm{c}, \mathrm{t}-1}$ & $\begin{array}{c}0.338 \\
(3.486)\end{array}$ & $\begin{array}{c}0.509 \\
(3.506)\end{array}$ & $\begin{array}{l}-0.384 \\
(3.233)\end{array}$ & $\begin{array}{l}-0.128 \\
(3.105)\end{array}$ \\
\hline $\operatorname{Size}_{\mathrm{b}, \mathrm{ct}-1}$ & $\begin{array}{c}-1.028^{* *} \\
(0.486)\end{array}$ & $\begin{array}{c}-1.051 * * \\
(0.490)\end{array}$ & $\begin{array}{c}-1.216^{* * *} \\
(0.455)\end{array}$ & $\begin{array}{c}-1.222^{* * *} \\
(0.437)\end{array}$ \\
\hline Liquidity $_{b, c, t-1}$ & $\begin{array}{c}1.327 \\
(1.260)\end{array}$ & $\begin{array}{c}1.251 \\
(1.246)\end{array}$ & $\begin{array}{l}2.818^{*} \\
(1.490)\end{array}$ & $\begin{array}{l}2.586^{*} \\
(1.405)\end{array}$ \\
\hline TLTRO $_{b, c, t-1}$ & $\begin{array}{c}0.0198 \\
(0.0413)\end{array}$ & $\begin{array}{c}0.0269 \\
(0.0402)\end{array}$ & $\begin{array}{l}-0.0413 \\
(0.0976)\end{array}$ & $\begin{array}{l}-0.0127 \\
(0.0423)\end{array}$ \\
\hline Dependent Variable $e_{b, c, t-1}$ & $\begin{array}{c}-0.0672^{*} \\
(0.0351)\end{array}$ & $\begin{array}{c}-0.0598^{*} \\
(0.0348)\end{array}$ & $\begin{array}{l}-0.0197 \\
(0.0326)\end{array}$ & $\begin{array}{l}-0.0171 \\
(0.0329)\end{array}$ \\
\hline Dependent Variable $\mathrm{b}_{\mathrm{b}, \mathrm{c}, \mathrm{t}-2}$ & $\begin{array}{c}0.0722^{* * *} \\
(0.0249)\end{array}$ & $\begin{array}{c}0.0774^{* * *} \\
(0.0257)\end{array}$ & $\begin{array}{c}0.0884^{* * *} \\
(0.0260)\end{array}$ & $\begin{array}{c}0.0887^{* * *} \\
(0.0265)\end{array}$ \\
\hline Dependent Variable $\mathrm{b}_{\mathrm{b}, \mathrm{c}, \mathrm{t}-3}$ & $\begin{array}{c}0.0181 \\
(0.0312)\end{array}$ & $\begin{array}{c}0.0225 \\
(0.0313)\end{array}$ & $\begin{array}{c}0.0457 \\
(0.0280)\end{array}$ & $\begin{array}{c}0.0439 \\
(0.0283)\end{array}$ \\
\hline Dependent Variable $e_{b, c, t-4}$ & $\begin{array}{l}0.173 * * * \\
(0.0342)\end{array}$ & $\begin{array}{l}0.177^{* * *} \\
(0.0340)\end{array}$ & $\begin{array}{l}0.177 * * * \\
(0.0287)\end{array}$ & $\begin{array}{l}0.178^{* * *} \\
(0.0291)\end{array}$ \\
\hline $\begin{array}{l}\text { Bank fixed effects } \\
\text { Country-time fixed effects }\end{array}$ & $\begin{array}{l}\text { Yes } \\
\text { Yes }\end{array}$ & $\begin{array}{l}\text { Yes } \\
\text { Yes }\end{array}$ & $\begin{array}{l}\text { Yes } \\
\text { Yes }\end{array}$ & $\begin{array}{l}\text { Yes } \\
\text { Yes }\end{array}$ \\
\hline Number of observations & 2524 & 2498 & 3305 & 3279 \\
\hline Number of banks & 82 & 77 & 107 & 102 \\
\hline $\mathrm{R}^{2}$ & 0.398 & 0.393 & 0.366 & 0.365 \\
\hline
\end{tabular}

Notes: The Balance sheet measure used in each specification is listed at the top of the respective column. Excess liquidity is used to proxy for the impact of the DFR; Sovereign bond holdings are used to proxy for the effects of the APP. The dependent variable is the quarterly growth rate of loans to the non-financial corporations during the period 2007Q4-2017Q4. Coefficients are listed in the first row, robust standard errors that are corrected for clustering at the bank level are reported in the row below, and the corresponding significance levels are indicated with stars. "Yes" indicates that the set of characteristics or fixed effects is included. "No" indicates that the set of characteristics or fixed effects is not included. ${ }^{* * *}$ Significant at $1 \%, * *$ significant at $5 \%, *$ significant at $10 \%$. 


\section{Acknowledgements}

We would like to thank seminar participants at the ECB, the National Bank of Belgium, the 6th Workshop in Macro Banking and Finance (Alghero), De Nederlandsche Bank, 33rd Annual Congress of the European Economic Association (Cologne) for their helpful comments and suggestions. Ongena acknowledges financial support from ERC ADG 2016 - GA 740272 lending. The opinions in this paper are those of the authors and do not necessarily reflect the views of the European Central Bank or the Eurosystem.

\section{Carlo Altavilla}

European Central Bank, Frankfurt am Main, Germany; email: carlo.altavilla@ecb.europa.eu

\section{Miguel Boucinha}

European Central Bank, Frankfurt am Main, Germany; email: miguel.boucinha@ecb.europa.eu

\section{Sarah Holton}

European Central Bank, Frankfurt am Main, Germany; email: sarah.holton@ecb.europa.eu

\section{Steven Ongena}

University of Zurich, Zurich, Switzerland; email: steven.ongena@bf.uzh.ch

\section{(C) European Central Bank, 2018 \\ Postal address 60640 Frankfurt am Main, Germany \\ Telephone +496913440 \\ Website www.ecb.europa.eu}

All rights reserved. Any reproduction, publication and reprint in the form of a different publication, whether printed or produced electronically, in whole or in part, is permitted only with the explicit written authorisation of the ECB or the authors.

This paper can be downloaded without charge from www.ecb.europa.eu, from the Social Science Research Network electronic library or from RePEc: Research Papers in Economics. Information on all of the papers published in the ECB Working Paper Series can be found on the ECB's website. 